\title{
DOES ECONOMIC GROWTH REDUCE CORRUPTION? THEORY AND EVIDENCE FROM VIETNAM
}

\author{
Jie Bai \\ Seema Jayachandran \\ Edmund J. Malesky \\ Benjamin A. Olken \\ Working Paper 19483 \\ http://www.nber.org/papers/w19483
}

\author{
NATIONAL BUREAU OF ECONOMIC RESEARCH \\ 1050 Massachusetts Avenue \\ Cambridge, MA 02138 \\ September 2013
}

We thank Lori Beaman, Raymond Fisman, Chang-Tai Hsieh, Supreet Kaur, Neil McCulloch, Andrei Shleifer, Matthew Stephenson, Eric Verhoogen, and Ekaterina Zhuravskaya for helpful comments. The PCI survey data used in this paper was funded by USAID, and was collected by Development Alternatives Incorporated with the cooperation of the Vietnam Chamber of Commerce and Industry. The views expressed here are those of the authors and do not necessarily reflect the views of any of these organizations or the National Bureau of Economic Research.

At least one co-author has disclosed a financial relationship of potential relevance for this research. Further information is available online at http://www.nber.org/papers/w19483.ack

NBER working papers are circulated for discussion and comment purposes. They have not been peerreviewed or been subject to the review by the NBER Board of Directors that accompanies official NBER publications.

(C) 2013 by Jie Bai, Seema Jayachandran, Edmund J. Malesky, and Benjamin A. Olken. All rights reserved. Short sections of text, not to exceed two paragraphs, may be quoted without explicit permission provided that full credit, including $(\mathcal{C}$ notice, is given to the source. 
Does Economic Growth Reduce Corruption? Theory and Evidence from Vietnam

Jie Bai, Seema Jayachandran, Edmund J. Malesky, and Benjamin A. Olken

NBER Working Paper No. 19483

September 2013

JEL No. D73,O11,O40

\begin{abstract}
$\underline{\text { ABSTRACT }}$
Government corruption is more prevalent in poor countries than in rich countries. This paper uses cross-industry heterogeneity in growth rates within Vietnam to test empirically whether growth leads to lower corruption. We find that it does. We begin by developing a model of government officials' choice of how much bribe money to extract from firms that is based on the notion of inter-regional tax competition, and consider how officials' choices change as the economy grows. We show that economic growth is predicted to decrease the rate of bribe extraction under plausible assumptions, with the benefit to officials of demanding a given share of revenue as bribes outweighed by the increased risk that firms will move elsewhere. This effect is dampened if firms are less mobile. Our empirical analysis uses survey data collected from over 13,000 Vietnamese firms between 2006 and 2010 and an instrumental variables strategy based on industry growth in other provinces. We find, first, that firm growth indeed causes a decrease in bribe extraction. Second, this pattern is particularly true for firms with strong land rights and those with operations in multiple provinces, consistent with these firms being more mobile. Our results suggest that as poor countries grow, corruption could subside "on its own," and they demonstrate one type of positive feedback between economic growth and good institutions.
\end{abstract}

Jie Bai

Department of Economics

Massachusetts Institute of Technology

77 Massachusetts Ave

Cambridge, MA 02139

jieb@mit.edu

Seema Jayachandran

Department of Economics

Northwestern University

2001 Sheridan Road

Evanston, IL 60208

and NBER

seema@northwestern.edu
Edmund J. Malesky

Duke University

Gross Hall

140 Science Drive

Durham, NC 27708

ejm5@duke.edu

Benjamin A. Olken

Department of Economics

Massachusetts Institute of Technology

77 Massachusetts Avenue

Cambridge, MA 02139

and NBER

bolken@mit.edu 


\section{Introduction}

A striking fact about government corruption is that, no matter how you measure it, it is higher in poor countries. For example, the 10 least corrupt countries in the 2009 Transparency International Corruption Perceptions Index, such as New Zealand, the Netherlands, and Canada, had an average real GDP per capita of $\$ 36,700$; the 10 most corrupt countries, such as Haiti, Turkmenistan, and Afghanistan, had an average real GDP per capita of $\$ 5,100$. This relationship is easy to see in the raw data: Figure 1 shows scatter plots of the two major corruption indices, the Transparency International Corruption Index and the World Bank Control of Corruption Index, plotted against real (i.e., PPP-adjusted) GDP per capita, and shows a clear downward-sloping relationship between corruption and GDP.

The strong correlation between economic development and corruption does not appear to be an artifact of misplaced perceptions. Data on individual bribe payments from household surveys conducted in several countries show the same pattern (e.g., Mocan (2004)), as do survey data collected from firms around the world. Figure 2 plots the fraction of firms surveyed by the World Bank Enterprise Survey that reported they were expected to give gifts to public officials in order to "get anything done" against real GDP per capita, and once again, there is a downward-sloping relationship.

While there is a general consensus about the cross-sectional facts, we know relatively little about why corruption is lower in rich countries. One hypothesis is that this pattern reflects a negative causal effect of corruption on economic growth: Corruption discourages investment which, in turn, depresses growth (Mauro, 1995; Wei, 1999a). Such a link suggests that rooting out corruption could be critical in achieving higher growth in developing countries.

However, the correlation between income and corruption could also reflect the reverse causal link: Economic growth may reduce corruption, so as countries grow, corruption naturally declines (Treisman, 2000). In this paper, we propose a mechanism through which this may occur, based on the idea of inter-regional competition. We model how economic growth affects the bribes that bureaucrats extract from firms, and then test the predictions using a data set of firms in Vietnam that includes information on the bribes the firms paid to government officials.

We begin by laying out a simple neoclassical model in which the government is able to extract an unlimited amount of bribes from a firm, for example, because it could shut down the firm if it does not comply. What puts a check on bribe extraction is that if the amount 
is too high, a firm will move elsewhere. The government chooses a percentage of a firm's revenues to extract as bribes, trading off higher bribe income generated by a higher bribe rate against the increase in the firm's incentive to leave.

The model predicts, under reasonable assumptions about firms' moving costs, that an exogenous increase in firm productivity reduces the proportion of firm revenues that are extracted as bribes. Specifically, the assumption needed is that moving costs are concave in firm size, which would be true for example if there is any fixed costs associated with moving. If this is true, then for a fixed bribe rate, a firm's net benefits of moving (reduced bribes minus moving costs) increase as the firm grows. To offset this greater incentive of firms to move, the government will respond by reducing the proportion of revenues that it extracts as bribes. Bribes become a smaller part of the economy as firms grow.

The model also predicts that if corrupt officials can price-discriminate among firms (as in, e.g., Svensson (2003)), this negative effect of growth on corruption will be heterogeneous, depending on individual firms' ability to move. Intuitively, if firms are completely tied to one region, then inter-regional competition as a check on the level of bribes vanishes. We show that this intuition also holds for how growth affects bribes: Economic growth reduces corruption by a greater amount if firms are more able to move elsewhere.

We examine the relationship between economic growth and corruption empirically, and show that the data are consistent the predictions of the model, using within-country variation and firm-level data from Vietnam. We use the Provincial Competitiveness Index (PCI) survey (Malesky, 2011), an annual survey of firms that asks how much the firm paid in bribes to government officials as a percentage of their revenues. We construct a repeated cross-section across province-industries from 2006 to 2010, comprised of data on a total of about 13,000 individual firms, and examine how the bribe-paying rate varies with firms' growth (or more precisely, with their predicted growth).

The PCI survey is designed to study the investment environment across Vietnam's 63 provinces and therefore collects data on a representative sample of firms in each province. The survey instrument asks respondents to reflect specifically on their interactions with provincial officials, allowing us to treat each province as a jurisdiction in which bureaucrats determine how much to extract from local firms. The reason the PCI specifically asks about dealings with provincial officials is that bureaucratic corruption is largely decentralized in Vietnam, with provincial governments, as opposed to the central government, wielding 
the most power to extract bribes from firms (Meyer and Nguyen, 2005; Cung, Tuan, Van, and Dapice, 2004, Tran, Grafton, and Kompas, 2009). This institutional feature informs our theoretical and empirical frameworks, in which we treat the province as the relevant geographic unit for bribe extraction and inter-provincial competition as a force that can keep corruption in check. There is also suggestive evidence of corruption as a factor in firms' location decisions: The most recent wave of the PCI collected data from some firms on what might prompt them to relocate, and 20 percent of them cited the quality of local governance.

As shown in Figure 3, during our study period of 2006 to 2010, nationally Vietnam was growing rapidly, and corruption as measured in the PCI was falling. These time trends are suggestive, but do not isolate the causal impact of growth on corruption. To test for a causal relationship, we use detailed micro data and track how shocks to predicted firm profitability affect the bribes that provincial officials extract from the firm. As a source of plausibly exogenous variation in a firm's economic performance, we predict a firm's size (employment level) using the aggregate size of the firm's industry in the rest of Vietnam, excluding the firm's province itself. This identification strategy is similar to the "shift-share" or Bartik approach that is commonly used (Bartik, 1991; Blanchard and Katz, 1992; Bound and Holzer, 2000). To construct this aggregate measure, we use a census of firms conducted by Vietnam's General Statistical Organization (GSO) and calculate aggregate employment at the province-industry-year level. We show that industry-wide performance is indeed a strong predictor of a firm's performance. 1

Using this approach, we find that when a firm's predicted growth increases, the rate of bribe extraction decreases, consistent with the model's predictions. To the best of our knowledge, this provides the first within-country causal evidence that economic growth leads to lower corruption.

We then test for the heterogeneous patterns predicted by the model. To capture heterogeneity in moving costs, we use variation in whether firms possess a Land Use Rights Certificate (LURC), which gives them secure and transferable property rights over their land. These property rights make firms more mobile, since they increase their ability to sell their land and relocate should they wish to do so.2 We test whether having more secure

\footnotetext{
${ }^{1}$ Growth in aggregate employment arises from both growth in the number of firms and employment growth of existing firms. Our theoretical predictions are about the growth of existing firms. Empirically, most of the growth in aggregate industry employment at the province-year level occurs via the growth of existing firms. See footnote 19 for further details.

${ }^{2}$ Several recent papers have documented an analogous positive effect of property rights over land on
} 
and transferable property rights enhances the negative effect of growth on corruption and find that it indeed does. When a firm owns the plot of land on which it operates and has official permits for that land - so that it is presumably more mobile - economic growth has a stronger negative effect on bribes.

We also find similar patterns using a second measure of mobility: having operations in multiple provinces. Firms with a presence in multiple provinces can more easily scale back operations in one province and shift elsewhere where they might be subject to less corruption. Thus, the economic growth should put more downward pressure on bribes for this group. We find empirical support for this prediction as well.

While the data are consistent with interjurisdictional competition being a mechanism through which economic growth reduces bribery, it is not the only potential mechanism for this effect. We discuss several alternative models, such as a fixed cost of enforcement or changes in industry concentration associated with the employment shock. A key differentiating factor is that these other models do not generally explain the fact that the responsiveness of bribes to shocks is stronger for firms that appear more mobile. While we argue that no other model explains the complete set of facts we find - so the model we lay out is likely at play - it is also important to note interjurisdictional competition is not the only possible mechanism and that other mechanisms likely also contribute to the overall effect of growth on bribery that we detect empirically.

Our findings make several contributions to the literature on corruption in developing countries. First, we provide some of the first micro empirical evidence on the effect of economic growth on corruption. Our finding that economic growth reduces bribery suggests that countries might "grow" their way out of corruption. In this case, it may not be necessary to root out corruption to spur growth, but rather corruption might subside as a country grows. ${ }^{3}$

Second, our findings contribute to the broader literature on the effects of economic growth on institutions, providing the first empirical evidence that we know of for the idea that interregional competition could reduce corruption and showing that this effect is greater for more

migration for individuals, showing that land titling in Mexico increased both domestic (de Janvry, Emerick, Gonzalez-Navarro, and Sadoulet, 2012) and international (Valsecchi, 2011) migration.

${ }^{3}$ At the cross-country level, the most related work is Treisman (2000), who finds that per-capita income, instrumented by geography, negatively predicts corruption. Treisman (2007), however, notes that this relationship does not necessarily hold once one uses microdata-based measures of corruption of the sort we examine here. 
mobile firms $4^{4}$ The literature on institutions and growth suggests that economic growth could improve the quality of political and economic institutions, and we confirm this hypothesis for the case of bureaucratic corruption (Acemoglu, Johnson, and Robinson, 2005, Glaeser, La Porta, Lopez-de Silanes, and Shleifer, 2004).

Third, our finding that better property rights for firms coupled with economic growth can reduce corruption adds to the literature on the economics benefits of property rights. Strong theoretical and empirical evidence exists for the relationship between property rights, domestic investment, and growth (North, 1991; De Long and Shleifer, 1993; Weingast, 1995 ; Goldstein and Udry, 2008; Jones, 1981; Acemoglu and Johnson, 2005; Olson, 2000). De Soto (1989) and De Soto (2000) famously predicted that through the provision of land titles, entrepreneurs in the informal sector could be transformed into an important source of economic growth in the developing world. Since the publication of that piece, convincing evidence has been found that allocation of land rights increases household investment Galiani and Schargrodsky, 2010), belief in the power and fairness of the market (Di Tella, Galiant, and Schargrodsky, 2007), and the number of hours dedicated to productive work (Field, 2007). We provide a new dimension to literature on the economic benefits of property rights by demonstrating how land titling can restrain the grabbing hand of local authorities in the presence of economic growth.

Besides contributing to the literatures on corruption and property rights, our paper is also related to the literature on inter-regional tax competition. The decision problem we model of a bureaucrat setting a bribe rate is analogous to the problem of local governments setting tax rates (Epple and Zelenitz, 1981; Epple and Romer, 1991; Wildasin, 2003; Wilson, 1986). A recent study by Diamond (2012) uses a similar framework to study the effect of workers' migration elasticity on the magnitude of rent extraction by state and local governments. Where we differ from her study and many previous tax competition papers is in the comparative statics we are interested in: We derive (and test) not just the determinants of the level of rents (taxes or bribes) but also the effects of economic growth in such an

\footnotetext{
${ }^{4}$ From a theoretical perspective, Rose-Ackerman (1978) and Shleifer and Vishny (1993) are among the first to argue that competition between bureaucrats can reduce corruption, though they consider a different framework than the one we present here. The closest analogue to the ideas developed here is Menes (2006), who noted in her qualitative study of US cities that the ability of firms to relocate to other jurisdictions was one potential reason why urban corruption in the pre-Progressive era was not more severe. Burgess et al. (2012) show in the context of illegal logging in Indonesia that Cournot-style competition between jurisdictions can decrease the price of bribes, though in their context that actually leads to more corrupt activity, rather than less.
} 
environment, which, to our knowledge, has not been a focus of the tax literature but could also apply in that context.

The remainder of the paper is organized as follows. Section 2 presents the model. Section 3 describes our data and background information on Vietnam. Section 4 describes the empirical strategy, and section 5 presents the results and discusses alternative explanations. Section 6 concludes.

\section{Model}

We consider a model in which governments choose how much to extract from firms to maximize their bribe revenue. Governments balance the revenues they raise from extracting higher bribes from firms with an increased risk that by extracting too much from firms in their jurisdictions, some firms may choose to relocate to other jurisdictions with lower corruption. For firms, a bribe is just an additional payment to government, analogous to a tax. The model is therefore similar to models of inter-regional tax competition, where we think of a bribe payment as a type of tax.

The basic idea that underlies most of the papers in the tax competition literature is that mobile factors can adjust their location to any inter-regional differentials in taxation or benefits. Local governments thus need to take into account such potential reaction when designing redistributive policies. Each local government chooses its tax parameters strategically trying to influence migration or capital movement. Models either assume that each region is a small economy among many, or that two regions (usually perfectly symmetric) play a Nash game, though the implications are generally robust to the choice of modeling approach. Cremer and Fourgeaud (1995) provide a comprehensive survey of this literature. In this paper, we adopt the second approach and consider a two-region Nash equilibrium.

The key distinction of our model compared to the previous literature is that we focus not just on the equilibrium level of taxes/bribes, but also examine how the level of bribes changes with productivity shocks. It is this comparative static that generates predictions about how economic development affects the amount of corruption in the economy. We also derive how the relationship between productivity shocks and the equilibrium bribe rate varies based on the firm's ease of relocating to another jurisdiction. In this section, we will set up the problem and state the key propositions. Details of the mathematical derivations 
and proofs can be found in the Appendix.

We assume that there are two provinces, denoted 1 and 2.5 Each province is endowed with a unit mass of incumbent firms. Government and firms play a static game and move sequentially. First, the government in each province $p$ sets a bribe rate $b_{p}$, which is the percent of a firm's revenues that it must pay in bribes ${ }^{6}$ Next, firms in each province choose whether to stay in the province or relocate to the other province. Finally, firms choose their factors of production, they produce, and the government collects bribes.

We begin by specifying the firm's problem, then the problem for local governments, and lastly characterize the equilibrium. Suppose all firms have the same two-factor Cobb-Douglas production function with diminishing returns to scale. We assume diminishing returns to scale in order to pin down firm size and generate profits in equilibrium. Capital and labor are perfectly elastically supplied at the same wage rate $w$ and interest rate $r$ in both provinces. Denote the bribe rate set in period 1 in province $p$ as $b_{p}$. We focus on the problem for firms in province 1 (naturally the analysis is symmetric for firms in province 2). A typical firm in province 1 solves

$$
\max _{K \geq 0, L \geq 0}\left(1-b_{1}\right) A K^{\alpha} L^{\beta}-w L-r K
$$

where $A$ is the total factor productivity of the firm. We can also think of $A$ as encompassing the price of the products in the firm's industry. This maximization problem yields the following familiar results:

$$
\begin{aligned}
\frac{L^{*}}{K^{*}} & =\frac{r}{w} \frac{\beta}{\alpha} \\
K^{*} & =\left(\frac{r}{\left(1-b_{1}\right) A \alpha}\left(\frac{r}{w} \frac{\beta}{\alpha}\right)^{-\beta}\right)^{\frac{1}{\alpha+\beta-1}} \\
\pi^{*} & =\left(1-b_{1}\right) A K^{* \alpha} L^{* \beta}-w L^{*}-r K^{*}
\end{aligned}
$$

In addition to affecting the firm's decision of whether to move as described below, the bribe rate also affects the firm's optimal choice of capital and its profits: the higher the rate of bribe extraction $b_{1}$, the smaller the firm's capital stock and profits will be.

\footnotetext{
${ }^{5}$ The same results apply in a context where we have a large number of jurisdictions, and firms everywhere face some fixed outside option.

${ }^{6} \mathrm{We}$ focus on bribes as a percent of revenues because this is the variable we observe in our empirical analysis. All of the results shown here go through if we instead use bribes as a proportion of the firm's capital stock $K$. Details for the alternative model are available upon request.
} 
The firm will choose to stay in province 1 if and only if profits in province 1 are greater than profits in province 2 less moving costs, i.e. if $\pi_{f 1}^{*} \geq \pi_{f 2}^{*}-m$, where $m$ is the firm's moving costs. To proceed, we need to impose some structure on the moving costs $m$. We specify the moving costs for firm $i$ as

$$
m_{i}=\theta A^{\eta} \epsilon_{i} .
$$

The term $A^{\eta}$ captures the fact that the moving costs should be increasing in firm size. For example, the firm's capital stock would need to be moved or sold and repurchased with transaction costs, and larger firms have a larger capital stock. Similarly, new employees would have to be recruited, hired, and trained, and larger firms have more employees. In the context of the model, $A$ is directly related to firm size; higher TFP firms have a larger capital stock and more employees, and therefore larger moving costs. 7 The exponent $\eta \geq 0$ captures the degree to which moving costs are increasing in the size of the firm.

Conditional on firm size, moving costs vary across firms in two ways. First, the $\theta$ term captures the part of the firm's moving costs that is observable to the government, with higher $\theta$ corresponding to higher moving costs. In our empirical analysis, we focus on a firm's property rights status and whether it has operations in multiple provinces as proxies for the observable components of its moving costs. Second, moving costs include a stochastic term $\epsilon$ that varies across firms. Crucially, while $\theta$ will be observable to the government in determining bribe rates, the idiosyncratic part of the moving costs $\epsilon$ is unobserved.

Putting the pieces together, a firm in province 1 chooses to stay if and only if

$$
\begin{aligned}
\pi_{1}^{*} & \geq \pi_{2}^{*}-\theta A^{\eta} \epsilon, \quad \text { or } \\
\epsilon & \geq \frac{\pi_{2}^{*}-\pi_{1}^{*}}{\theta A^{\eta}}
\end{aligned}
$$

To simplify the algebra, we further assume that $\epsilon$ is uniformly distributed over $[0,1]]^{8}$ The

\footnotetext{
${ }^{7}$ Note that all of our key results are robust to instead parameterizing the moving costs in terms of the capital stock $K^{*}$, rather than in terms of $A$, but this is more complicated because $K^{*}$ is endogenously determined, whereas $A$ is an exogenous parameter of the model. To do so, one could parameterize moving costs as $\theta K^{* \eta} \epsilon_{i}$, where $K^{*}$ refers to the equilibrium level of capital that is chosen in province 1 . The idea is that if you move, you must move your existing capital stock to province 2, and then readjust. Details for this alternative model are available upon request.

${ }^{8}$ This assumption simplifies the algebra but is not essential; all of the key results go through for arbitrary distributional forms of the error term.
} 
equilibrium number of firms for a given $\theta$ in province 1 is therefore simply $1-\frac{\pi_{2}^{*}-\pi_{1}^{*}}{\theta A^{\eta}} .9$ Since the problem is symmetric for both provinces, this expression will be greater than 1 if $b_{1}<b_{2}$ (firms are moving into province 1 from province 2), and less than 1 if $b_{1}>b_{2}$ (firms are moving out of province 1 to province 2 ).

The two governments in period 1 set bribe rates, taking firms' response and the other province's bribe rate as given. To solve this, we consider the government in province 1 . It takes $b_{2}$ as given and solves,

$$
\max _{b_{1} \geq 0} b_{1} A K^{* \alpha} L^{* \beta}\left(1-\frac{\pi_{2}^{*}-\pi_{1}^{*}}{\theta A^{\eta}}\right)
$$

Assuming a symmetric equilibrium, the first-order condition can be simplified to:

$$
K^{*}+b_{1}^{*}(\alpha+\beta) \frac{d K^{*}}{d b_{1}}+\frac{b_{1}^{*} K^{*}}{\theta A^{\eta}} \frac{d \pi_{1}^{*}}{d b_{1}}=0
$$

After some algebra, we get:

$$
\left(\frac{1}{\theta} A^{1-\eta}\left(\frac{r \beta}{w \alpha}\right)^{\beta} K^{* \alpha+\beta}+\frac{\alpha+\beta}{1-\alpha-\beta} \frac{1}{1-b^{*}}\right) b^{*}=1
$$

Note that we have suppressed the province subscript since $b_{1}^{*}=b_{2}^{*}$ in equilibrium.

Several aspects of the equilibrium condition in Equation (9) are worth noting. First, as $\theta$ goes to $+\infty$, or firms are completely immobile, the expression simplifies such that $b^{*}=1-\alpha-\beta$. This implies that the greater the diminishing returns to scale, the higher the bribe rate. Intuitively, if output is highly concave in capital, even when the bribe rate is reduced, firms will not expand their capital stock much due to diminishing returns. Thus, the elasticity of capital with respect to the bribe rate is low. The same applies to labor. Therefore, when the government increases the bribe rate, it can extract more revenue from firms without discouraging production. Hence, the optimal bribe rate is higher.

The second observation is that as $\theta$ decreases, so that moving costs decrease, inter-

\footnotetext{
${ }^{9}$ Even though we have in mind a world of many firms with heterogenous $\theta$, we are solving the model for a particular $\theta$. (This would correspond to firms with the same property right status or same status of single or multi-province operations in our empirical section.) After we obtain the equilibrium bribe rate, which is a function of $\theta$, we will examine how bribes and the effect of firm growth on bribes vary with $\theta$. It is important to bear in mind that by doing so, we are assuming there is no interaction, either through factor markets or products market, among different types of firms. This is a non-trivial simplifying assumption, but it makes the problem tractable.
} 
regional competition increases and the equilibrium bribe rate decreases. Thus far, the model captures the idea that increasing competition between political jurisdictions can drive down corruption, as in Shleifer and Vishny (1993) and Burgess et al. (2012).

Next, we examine how the equilibrium bribe rate responds to increases in the profitability of firms, i.e. increases in $A$. Taking the derivative with respect to $\log A$ on both sides of Equation (9) and re-arranging terms, we get our first result:

Proposition 1. $\frac{d b^{*}}{d \log A}<0$ if $0 \leq \eta<\frac{1}{1-\alpha-\beta} ;=0$ if $\eta=\frac{1}{1-\alpha-\beta}$; and $>0$ if $\eta>\frac{1}{1-\alpha-\beta}$.

The critical factor that determines the $\operatorname{sign}$ of $d b^{*} / d \log A$ is $\eta$, which characterizes the concavity of the moving costs with respect to the capital stock. The intuition is that with a positive shock to $A$, for a given size, firms enjoy higher revenues and hence care more about the bribes they will pay and less about the moving costs. This tends to drive down the equilibrium bribe rate due to inter-regional competition. However, at the same time, the cost of moving rises as firms expand in size to take advantage of the higher productivity. This instead tends to drive up the equilibrium bribe rate. The two effects exactly cancel at $\eta=\frac{1}{1-\alpha-\beta}{ }^{10}$ If $\eta<\frac{1}{1-\alpha-\beta}$, then the first effect (inter-regional competition effect) dominates the second effect (moving cost effect), and the equilibrium bribe rate falls. Given that $1-\alpha-\beta<1$, a sufficient condition for $\frac{d b^{*}}{d \log A}<0$ is that moving costs scale up less than linearly with firm size, as proxied by $A$. In practice, since moving entails at least some element of fixed costs and, moreover, since $1-\alpha-\beta$ can in fact be much less than 1 , it seems plausible that $\eta<\frac{1}{1-\alpha-\beta}$ and therefore $d b^{*} / d \log A<0$ in most settings. We will test this prediction in the empirical section below 11

Proposition 1 specifies conditions when the rate of bribe extraction falls as $A$ increases; the rate $b$ is the size of the distortion to production. It is worth noting that another (testable) prediction is that the total amount of bribes extracted from the firm will increase when $A$ increases. To see this note that the firm's moving decision is a tradeoff between its total

\footnotetext{
${ }^{10}$ Though the specific cut-off value for $\eta$ at which the sign of the comparative statics switches depends on the Cobb-Douglas functional form for production and the particular parameterization of the moving costs, the general intuition is robust: The more concave the moving costs with respect to firm size are, the more likely that equilibrium bribe rate decreases with $A$.

${ }^{11}$ To the extent that taxes follow similar patterns to bribes, another implication of the model is that taxes on firms should also be lower in rich countries than in poor countries. This turns out to be true: Gordon and Li (2009) show that for poor countries (with per-capita GDP below $\$ 745$ ), corporate income taxes represent 7.5 percent of GDP, whereas for rich countries (with per-capita GDP above $\$ 9,200$ ), corporate income taxes represent only 4.5 percent of GDP, although they suggest a different explanation than the one proposed here.
} 
moving costs and its total bribes. Since when $A$ increases, the firm's moving costs increase, the government can retain the same firms even with a higher total bribe extraction.

Next, we examine how the effect of a productivity shock on bribes varies across firms with different $\theta$. As discussed above, we focus on the firm's property right status or multi-province operations as the empirical analogue of $\theta$, where higher $\theta$ corresponds to less transferable property rights or concentration of operations in one province and thus a higher cost of moving. The next proposition derives how the elasticity of bribes with respect to productivity varies with $\theta$.

Proposition 2. If $0 \leq \eta<\frac{1}{1-\alpha-\beta}$, the elasticity $-\frac{d \log b^{*}}{d \log A}$ is monotonically decreasing in $\theta$, that is, $\frac{d^{2} \log b^{*}}{d \log A d \theta}>0$.

Intuitively, Proposition 1 implies that bribes fall when there is an increase in $A$, because more profitable firms are more willing to pay moving costs and escape from high bribe rates. Proposition 2 states that the bribe rate falls more after such a shock for firms with lower observable moving costs because the fraction of firms who are on the margin of moving is larger, so a given change in bribes will induce a larger number of them to leave ${ }^{12}$ We will test these predictions in the empirical part of this paper below.

\section{Setting and data}

\subsection{Background on Vietnam}

Vietnam provides a unique opportunity to test the implications of our model. At its 6th Party Congress in 1986, the country initiated the Doi Moi (Renovation) economic reforms, which eliminated the role of central planning in the economy and opened the country's borders to international capital and trade flows (Fforde and De Vylder, 1996, Riedel and Turley, 1999). Since that time, the country has achieved an average annual growth rate of 7.3 percent, ranking it among the very fastest growing countries in the world over the period.

Three post-Doi Moi events are critical for understanding the role these drivers play in Vietnam's economic development and the context of our research design. The Enterprise

\footnotetext{
${ }^{12}$ Note that Proposition 2 is stated in terms of elasticity or percentage change in the bribe rate (i.e. the change in $\log b$ ). The sign for the cross-partial of the level change (ie. $\frac{d^{2} b^{*}}{d A d \theta}$ ) is in general indeterminant because though the elasticity falls with $\theta$ (under the condition in Proposition 2), the level of bribe also falls with $\theta$. In particular, we can show that the relationship between $\frac{d b^{*}}{d A}$ and $\theta$ is $\mathrm{U}$-shaped and increasing as $\theta \rightarrow \infty$, and $\frac{d^{2} b^{*}}{d A d \theta}>0$ for a reasonable range of $\theta$ as assessed by the ratio of moving costs to revenue.
} 
Law in 2000 created the formal legal basis for the private, corporate sector in Vietnam and eased registration into all non-restricted activities. One year after the Enterprise Law, Vietnam finalized the long-standing negotiations with the United States over their bilateral trade agreement (US-VN BTA), which granted Vietnam Most-Favored Nation (MFN) status in accessing US markets. Finally, in 2007 Vietnam joined the World Trade Organization. Combined, these reforms led the period we study to be one of dramatic expansion in private activity in Vietnam: today, there are well over 350,000 private companies in Vietnam, operating in a range of sectors from food processing and light manufacturing to sophisticated financial services. The degree of economic growth over this period varied substantially across provinces, as shown in Figure 4.13

Despite this growth, there is still substantial corruption in Vietnam. For example, most international perceptions-based indices put Vietnam around the 30th percentile of corruption (where lower is more corrupt). Similarly, Transparency International's Global Corruption Barometer reports that 44 percent of Vietnamese report paying a bribe in 2011 (Transparency International, 2011).

Existing research has noted that corruption in Vietnam takes three main forms: grease or speed money to fulfill basic tasks or services; the illegal privatization of state property; and the selling of state power (Vasavakul, 2008). While all are undoubtedly important, the first is the most directly observable. About grease money, Vasavakul (2008) writes that, "A number of studies on informal payments [by individuals] show informal bribery totals from 100,000 to 2.1 million VND (roughly 5 to 100 USD) [per individual per year]. The key recipients are the traffic police, land cadres, customs officers, and tax authorities." These same offices were highlighted as the most corrupt in an internal study prepared by the Party's Internal Affairs Committee (Central Committee of Internal Affairs, 2005). Gueorguiev and Malesky (2011) document that the same types of bribes are common for firms, finding that 23 percent of businesses paid bribes to expedite business registration, 35 percent paid bribes when competing for government procurement contracts, and 70 percent paid bribes during customs procedures.

An important institutional feature of Vietnam is that corruption is largely subnational. Via a series of laws in the early 1990s, most business-government interactions were decentral-

\footnotetext{
${ }^{13}$ Figure 4 uses provinces' reports of their GDP, which, when aggregated, give a higher national GDP and growth rate than the official national statistics, which are likely more accurate. Thus, while the figure demonstrates the heterogeneity in growth across provinces, the levels shown are likely inaccurately high.
} 
ized to the provincial level. These include business registration, environmental and safety inspections, labor oversight, local government procurement, and land allocation. In practice, provincial departments of line ministries are "dual subordinate," meaning they report both to the provincial executive (the People's Committee Chairman, or PCOM), as well as the relevant national line ministry. In practice, however, appointments of department directors and budget allocations are set by the PCOM, closely aligning department interests with those of the province. Moreover, proximity matters. The PCOM interacts with department directors regularly, while the line ministries are hundreds of kilometers away in Hanoi. As a result, many studies have documented that the provincial government, more than the central government, is the relevant level of government when thinking about the institutional climate facing firms, including the degree of bribe extraction (Meyer and Nguyen, 2005; Cung, Tuan, Van, and Dapice, 2004, Tran, Grafton, and Kompas, 2009; Malesky, 2008).

As with all measures of governance in Vietnam, there is a high degree of subnational variation in firms' responses about corruption in the data we use. Figure 5 shows the distribution across provinces of the average response by firms for two corruption questions from the PCI survey in 2010, the last year of our sample period. In the worst-scoring province, 77 percent of private firms reported that firms in their line of business were subject to bribe requests. In the best-scoring province, a substantially smaller 15 percent claimed such activities were common. Similarly, high inter-provincial variation is observed for the share of revenue paid in bribes by firms, the core dependent variable in our analysis. In 2010, 16 percent of firms in the most corrupt province said bribe payments exceeded 10 percent of their annual revenue, compared to 0 percent in the lowest province. It is this spatial variation, along with temporal and cross-industry variation, that we seek to explain in our empirical analysis.

\subsection{Description of data}

To examine the effect of growth on corruption, we use two firm-level data sets from Vietnam, the Vietnam PCI Survey (Malesky, 2011), and the annual enterprise survey collected by the General Statistics Office of Vietnam, henceforth referred to as the PCI and GSO data, respectively. For each data set, we have five years of repeated cross-sectional firm-level data 
from 2006 to 201014

The PCI survey is a comprehensive governance survey of formal sector firms across Vietnam's 63 provinces 15 The survey team randomly sampled from a list of at least partly private companies registered with each province's tax authority. Stratification was based on firm size, age, and broad sector (agriculture, services, construction and industry) in order to accurately reflect the population of firms in each province. The PCI survey contains basic firm-level information, including the firm's ISIC 2 digit industry code, location (province), year of establishment, total assets, and total employment.

What makes the PCI survey well-suited for our study is that it has a module on corruption and red tape faced by the firm. The most relevant question that matches our theoretical predictions is the amount of unofficial payments to public officials the firm makes, expressed as a percentage of its revenue, which maps almost precisely to $b$ in our model. To the best of our knowledge, this data set is the only frequently repeated cross-section of firms' corruption experiences that is representative at the sub-national level in the developing world.

Table 1 presents summary statistics for the firms in the PCI data. Note that we merge the PCI firms with aggregate information from the GSO survey at the industry-provinceyear level. For industry, we use the ISIC alphabetical category. Thus, the PCI firms in our sample are those with non-missing data on industry whose province-industry-year is represented in the GSO data. Our final analysis data set contains 13,160 firms that meet this sample inclusion criterion.

The key dependent variable is constructed from the PCI question that asks the firm its unofficial payments as a percentage of total revenue, which corresponds to $b$ in our model. The question is categorical, with the following possible responses: $0,<1 \%, 1-2 \%, 2-5 \%$, $5-10 \%, 10-20 \%, 20-30 \%,>30 \%$. We transform this into a scalar variable by assigning each response the middle of the corresponding bin, using $0.5 \%$ for the $<1 \%$ category and $35 \%$ for the $>30 \%$ category. The mean of this variable is $3.8 \%$. While this may seem small, recall that this is a percent of revenues, not profits. If firms averaged $10 \%$ net profit margins, for example, this would be the same magnitude as a $38 \%$ profit tax. (In the empirical section

\footnotetext{
${ }^{14}$ The PCI survey is conducted in the early part of each calendar year (March-June). Information about firm's business and operations refer to the previous calendar year. For variables regarding bribe payment, it is reasonable to think that firms are also reporting based on past year's experiences. We therefore lag the PCI survey by one year before merging with the GSO data. The 2006 to 2010 timeframe thus corresponds to the PCI surveys conducted in early 2007 through early 2011.

${ }^{15}$ In 2008, Ha Tay province was merged with Hanoi, reducing the number of provinces from 64 to 63.
} 
below, we also consider an alternative specification using ordered probit models that allows the model to determine appropriate breakpoints; results are similar).

The median firm in our sample has been in business for four years and has 21 employees. Figure 6 shows the relationship between the bribe rate and firm size in our sample. Larger firms pay a smaller percentage of their revenues in bribes. Our empirical test of the model will use industry-province-year variation, but it is reassuring that the basic cross-sectional pattern in the data matches the model's prediction that a higher $A$ implies a lower $b$.

In addition to corruption activities, the PCI also has variables related to the firm's property rights status that we can use as measures of the firm's mobility, such as whether the firm owns the land that it occupies and whether the firm has a Land Use Rights Certificate (LURC). We will discuss these variables in more detail when we discuss the empirical results. The second proxy for mobility we have in the data is how many provinces the firm operates in. Most firms are wholly based in one province, but 8.2 percent have operations in provinces besides their main location.

Table 1 also summarizes several control variables we use, including the proportion of registration documents the firm has (a proxy for formality), whether the firm was formerly a household firm, whether it is a former state-owned enterprise, whether the owner is a government official, and whether the government has an ownership stake in the firm.

Our empirical strategy uses aggregate shocks to a firm's industry size as a predictor of the firm's size. Since the PCI is a sample, not a census, to measure the total employment in an industry in each year, we use the annual GSO census of firms in Vietnam to construct industry size. The GSO data include all formal sector firms in Vietnam, both private and state-owned. We restrict our sample to private firms in order to match with the PCI, and then merge the aggregate industry-province-year GSO measures to the PCI firms, at the industry-province-year level. We use the ISIC alphabetical industry codes in both data sets for our analysis. In the final merged data set, we have 18 distinct industry categories (see Appendix Table 1 for a description of the industries). Mean employment among firms in the GSO data is 23, similar to the level in the PCI. The main GSO variable we use in the analysis is the log of aggregate employment in the industry-province-year, which is also summarized in Table 1 . 


\section{Empirical strategy}

In the model laid out above, we considered the effect of a shock to $A$, total factor productivity, on bribes, or more specifically, bribes as a percentage of the firm's revenues. The predictions are that an increase in $A$ should decrease the bribe rate (Bribes), and that this pattern should be less true when moving costs (MovingCost) are higher. With data on firms indexed by $i$ in province $p$, industry $j$, and time $t$, one could in principle translate Propositions 1 and 2 to the data as follows:

$$
\begin{aligned}
& \text { Bribes }_{i p j t}=\alpha+\beta A_{i p j t}+\epsilon_{i p j t} \\
& \text { Bribes }_{i p j t}=\alpha+\beta A_{i p j t}+\gamma A_{\text {ipjt }} \times \text { Moving Cost }_{i p j t}+\delta \text { Moving Cost }_{i p j t}+\epsilon_{i p j t}
\end{aligned}
$$

The model's predictions are that $\beta$ in Equation 10 is negative, so that on average growth reduces bribes, and that $\gamma$ in Equation (11) is positive, so that the reduction in bribes as $A$ increases is smaller for firms with higher moving costs.

There are two issues with estimating Equations (10) and (11) directly. The first is a data problem: we do not directly observe TFP in the data, so, empirically, we use a firm's total

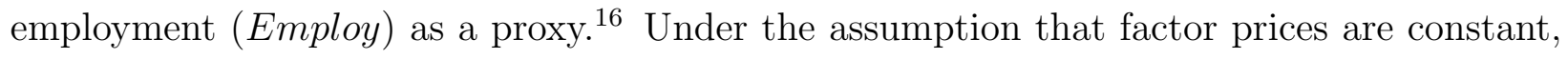
changes in employment reflect changes in $A$, so to the extent we can find a measure of employment that is exogenous with respect to the bribe rate $b$, we can replace $A$ with Employ and test the same predictions.

Of course, as is clear from Equation (1) in the model, a second issue is that employment levels are potentially endogenous to the bribe level $b$. Thus, we use an instrumental variable (IV) strategy to estimate Equations (10) and (11). The instrumental variable we use is employment in the firm's industry in provinces other than its own, controlling for common national year fixed effects and province-by-industry fixed effects. The IV strategy is predicated on industry-specific employment (or TFP) shocks in an industry being similar across provinces (i.e., on there being a strong first stage). The approach is similar to a Bartik shift-share instrument in that we are assuming that the size of an industry is different across provinces, but changes in the industry size within a province can be predicted by aggregate growth of the industry in other provinces. (See, for example, Bartik (1991), Blanchard

${ }^{16}$ The reason we cannot calculate TFP directly is that we do not have measures of revenue, capital stock, and wages in our data. 
and Katz (1992), and Bound and Holzer (2000) ).17 The identification assumption is that industry-specific bribe-setting is determined independently by each province. In particular, we are ruling out a large-scale national crackdown on corruption specific to an industry in a given year, which would violate this assumption (note that a national crackdown across all industries would be absorbed by year effects and would not be a problem for our identification strategy; likewise, different average levels of corruption in different regions or industries would be absorbed in region-by-industry fixed effects and would not be a problem). The assumption matches the institutional context of corruption in Vietnam as discussed above.

Our first stage specification is as follows:

$$
\log \text { Employ }_{p j t}=\alpha+\beta \log \text { Employ }_{p^{-} j t}+\nu_{p j}+\mu_{t}+\epsilon_{p j t} .
$$

The outcome variable, $\log E m p l o y_{p j t}$, is log total employment for industry $j$ in year $t$ in province $p$. The variable $\log E_{\text {mploy }} p^{-}$t is $\log$ total employment for firms in industry $j$ and year $t$ in all provinces other than $p$. We control for province-industry $(p j)$ and year $(t)$ fixed effects, so the specification is capturing differential changes in employment across industries over time, netting out common national time trends and different average levels by province-by-industry cell.

To examine the effect of exogenous productivity shocks on bribes, we estimate the reduced form equation:

$$
\text { Bribes }_{i p j t}=\alpha+\beta \log \text { Employ }_{p^{-} j t}+\nu_{p j}+\mu_{t}+\epsilon_{i p j t}
$$

The dependent variable is the amount that firm $i$ paid in bribes as a percentage of its revenue in year $t$. We control for province-industry and year fixed effects, as in the first stage. The regressor of interest varies at the industry-province-year level but to correct for possibly correlated errors across time and industry, we cluster standard errors at the province level. We also estimate the analogous IV regression, instrumenting for log Employ pjt $_{\text {with }}$ $\log$ Employ $_{p^{-}}{ }$.

To explore heterogenous effects with respect to the firm's cost of relocating to another

\footnotetext{
${ }^{17}$ Unlike in the standard Bartik setup, we do not need to aggregate the industry-level shocks back up to the region-year level (province-year in our case) since our outcome variable is available at the disaggregated industry-region-year level (and in fact firm level).
} 
province, we add interaction terms to Equation (13):

$$
\begin{aligned}
\text { Bribes }_{\text {ipjt }}= & \alpha+\beta \log \text { Employ }_{p^{-} j t}+\delta \text { MovingCost }_{\text {ipjt }} \\
& +\gamma \log \text { Employ }_{p^{-} j t} \times \text { MovingCost }_{i p j t}+\nu_{p j}+\mu_{t}+\epsilon_{i p j t} .
\end{aligned}
$$

The prediction from the model is $\gamma>0$, or that the negative effect of firm productivity (proxied by size) on bribes as a percent of revenue is smaller in magnitude when firms are more mobile. We test these hypotheses and present the results in the next section.

\section{Results}

In this section, we present evidence that a positive shock to aggregate productivity decreases unofficial payments by firms, and the decrease is bigger for firms that are more mobile, specifically those that have better property rights or have operations in multiple provinces. These results are consistent with the model's predictions.

\subsection{First stage results}

We estimate the first stage regression as specified by Equation (12). To do so, we use the GSO data and compute total employment at the $p j t$ and $p^{-} j t$ level. Each observation in the regression is a pjt (province-industry-year) combination.

As discussed above, the GSO data is a census of all firms in Vietnam in a given year. We can either run the first stage for all firms, or we can restrict our sample to only private firms. Since the PCI data only contains private firms, the most appropriate aggregate measures of firm productivity to predict outcomes in the PCI are based on only using private firms, so we make this sample restriction in the GSO.

We report the first stage results from estimating Equation (12) in Table 2. We classify firms into their alphabetical ISIC code (18 industries in total) ${ }^{18}$ We report standard errors clustered at the province level throughout.

Table 2 shows that the first stage coefficient is positive and significant at the 1 percent level. The coefficient on log Employ $p^{-}$jt is 0.724 . This means that for a 10 percent increase in

\footnotetext{
${ }^{18}$ We have an equally strong first stage using the finer two-digit ISIC codes, but the broader alphabetical codes are more robust to differences in classification across the GSO and PCI data sets.
} 
total employment in other provinces for industry $j$ in year $t$, there is an 7.24 percent increase in one's own province. Theoretically, if the aggregate shock propagates to all regions equally, we should observe a coefficient of 1 ; the coefficient of 0.724 suggests that much but not all of the temporal variation in productivity in Vietnam is aggregate to an industry.

Ideally, we would have constructed our instrument using the same data set that has our outcome (bribe) data. However, as discussed above, the PCI data, which has information on bribes and firm mobility, is a sample, and does not include all firms. As such, while the PCI is suitable for examining how a typical firm changes, we cannot use it for accurately calculating aggregate shocks. For example, an increase in prices for goods sold by industry $j$ (which is equivalent to an increase in $A$ in the model) might lead to entry of firms, so even though $A$ increased, average firm size might decrease 19 For this reason, we use the GSO data, which is a census, to construct our instrument. However, before proceeding, it is important to make sure that the PCI firms are a reasonably representative sample of all firms in the GSO data, and that the industry codes we merge on are comparable across the data sets. If not, then the reduced form results from regressing bribes as measured in the PCI data on the GSO-based instrumental variable could be spurious, or null results could reflect poorly matched data.

To cross-validate the two data sets and ensure that we are matching them appropriately, we compare mean and median firm employment among private firms for each pjt group. One issue with the PCI data is that employment is coded as a categorical variable: 10 to 50, 50 to 100, etc. To assign cardinal values to these bins, we compute the empirical mean and median employment for all firms in GSO for each of these PCI bins, and use these values to create the cardinal employment measure for the PCI firms. We then run the following

\footnotetext{
${ }^{19}$ Even if average firm size falls because of entry, an increase in $A$ will generally lead to growth on both the intensive and extensive margin. However, the instrument would be a weak proxy for an existing firm's employment growth if shocks to $A$ only affect the extensive margin. In our setting, there is correlated growth along both margins: The instrument is highly correlated with both average firm size in the GSO data and the number of firms. If we regress log mean employment and log total number of firms in province-industryyear group on the instrument, controlling for province-industry and year fixed effects, the coefficients are 0.397 and 0.328 respectively; both are significant at the 1 percent level. Mathematically, the sum of the two coefficients equals to the coefficient of regressing the endogenous variable, log total employment in the province-industry-year group, on the instrument. Hence, the ratio of the two coefficients to their sum tells us how much of a shock to the instrument affects the intensive and extensive margin. Reassuringly, about 55 percent $(=0.397 / 0.725)$ is on the intensive margin.
} 
regression, with province-industry and year fixed effects:

$$
\log E_{\text {mploy }}^{P C I}=\alpha+\beta \log \text { Employ }_{p j t}^{G S O}+\nu_{p j}+\mu_{t}+\epsilon_{p j t}
$$

If the PCI firms are a perfect random sample of GSO firms, stratified by province, industry and year, we should have $\beta=1$. We report the estimates in Appendix Table 2. We can see that the changes in mean employment in PCI and mean employment in GSO are positively correlated: $\beta$ is about 0.531 and significant at the $1 \%$ level. Similarly, the median employment in PCI and median employment in GSO are positively correlated and the coefficient is 0.478 and highly significant. These results confirm that, while the match between the two data sets is not perfect, they are indeed comparable, even looking just over time at changes within a given province-industry cell.

\subsection{Effect of employment growth on bribes}

Our outcome variable, which measures the degree of corruption firms face, is the unofficial payments as a percentage of revenue. As discussed above, it is a categorical variable, which we linearize by using the middle of each category. We estimate two versions of Equation (13), one using the linearized variable and one using an ordered probit specification that allows the regression to determine the precise cardinalization of each of the categories.

The results from estimating Equation (13) are shown in Table 3. Columns 1 and 2 report the reduced form results, using a linear model and an ordered probit model respectively, and Column 3 reports the IV estimate. All specifications control for province-industry and year fixed effects, and standard errors are clustered at the province level.

The reduced form results in Column 1 show that the coefficient for $\log E m p l o p_{p^{-}}$it is -1.72 , and significant at the 5 percent level. Growth in firm employment leads to a drop in the rate of bribe extraction from firms. Column 2 reports the results from an ordered probit specification. The coefficient is again negative and significant at the 5 percent level. The

ordered probit results suggest that the negative relationship shown in column 1 is not merely driven by the OLS functional form. Column 3 shows the IV coefficient, which suggests that a 10 percent increase in a firm's employment level leads to a 0.23 percentage point decline in the bribe rate.

To interpret magnitudes, note that column 3 implies that a doubling of total employment 
in the industry is associated with a 1.6 percentage point reduction in informal payments, or about 42 percent of the mean level. Translated into an elasticity, this suggests an elasticity of the informal payment rate (i.e. the share of revenues devoted to informal payments) with respect to predicted firm size of about -0.6. Since this elasticity is substantially less than 1 in absolute value, it implies that while the share of firm revenues paid in bribes (i.e. $b$ in the model) declines as $A$ increases, total unofficial payments, which are $b$ multiplied by revenues, increase. While of course $b$ is the key parameter that determines aggregate distortions due to corruption (see Equation (3)), it is worth noting that given this elasticity, the amount of corruption in absolute dollar terms actually increases even though the rate does not, consistent with the model's predictions.

\subsection{Heterogeneous effects based on firms' moving costs}

The evidence presented above finds that economic growth (specifically, an increase in firm employment) reduces the rate of bribe extraction. While this evidence is consistent with the model, the specific inter-jurisdictional competition idea outlined in our model is not the only explanation for why an increase in employment reduces bribes. For example, it is possible that bureaucrats simply have diminishing marginal utility of income relative to the risk of being caught and going to jail, so that as it becomes easier to extract revenues, they reduce rates. However, a key prediction of our model, as opposed to potential alternative explanations, is that the effect of an increase in $A$ on the bribe rate $b$ should be greater in magnitude when firms are more mobile.

To examine this prediction, we test for heterogeneous effects based on measures that seem plausibly correlated with firm mobility. In particular, we examine heterogeneity across firms with differing property rights over the land they operate on, and across firms that differ in whether they are based in one province or multiple provinces.

\section{Property rights}

In Vietnam, firms can have three types of tenure over the land on which they operate: renting, owning the land with official land use rights, and owning the land without official land use rights.20 Specifically, for firms that have purchased their land, they may or may

\footnotetext{
${ }^{20}$ Note that while we use the term "own," the more precise term would be "purchased" since in Vietnam, firms can purchase land, but in a technical sense, the state still owns all of the land.
} 
not have a land use rights certificate (LURC). Firms, intending to strengthen their property rights, submit the LURC application and related documents, such as map of the area and business plan, to the provincial Land Use Right Registration Office (LURRO). The LURRO does not evaluate the application, but simply checks the completeness of the application and supporting documents. It is required to inform the firm whether additional information is needed within three days of the application. After the LURRO inspection, the application is sent to the Provincial People's Committee (the local executive office) for evaluation and verification. While the People's Committee is legally obligated to respond within 50 days, in practice, waiting periods are substantially longer - often over a year or more. These waiting periods pose the largest obstacle to LURC acquisition ${ }^{21}$

Conditional on having purchased land, having an LURC makes it easier for the firm to move, because the firm can sell or trade its certificate if it decides to relocate to another province ${ }^{22}$ However, if a firm purchased the land it occupies but does not have a land use rights certificate, it is difficult for the firm to move for two reasons. First, it is costly and difficult to obtain land in a new province for business operations. More importantly, firms without LURCs will have difficulty obtaining the true commercial value of their land when they try to sell. Land without LURCs is known to be less valuable, as it can easily be expropriated by local authorities (Kim, 2004; Do and Iyer, 2003). Consequently, they will find it more difficult to relocate.

It is not ex ante obvious whether firms that rent face higher or lower relocation costs than those that own. For example, renters cannot recoup the value of any improvements they made to the property and may be locked into hard-to-renegotiate long-term leases, but they do not face transaction costs from having to sell property. What is clear though is that conditional on owning, transaction costs are lower for those with an LURC. We therefore examine heterogeneity across these different levels of moving costs: firms that rent land versus purchased land, and conditional on having purchased land, firms that have LURCs versus those that do not.

We estimate a model that interacts Employ $p_{p^{-} j}$ with these measures of property rights. In general, since we have a repeated cross-section of firms, not a panel, there is a potential

\footnotetext{
${ }^{21}$ Decree No. 88/2009/ND-CP dated 19 October 2009 on grant of certificates of land use rights and house and land-attached asset ownership; 2003 Land Law, amended and supplemented in 2009.

${ }^{22}$ Even though LURC trading was possible since 1993, it only became widespread with the 2003 Land Law. The overtime variation we see in the data comes from firms learning about the process and whether it benefits them.
} 
endogeneity problem if we use $\theta$ at the firm level (e.g., firms could adjust their $\theta$ in response to a shock in $A$ ). For the LURC variable, we know the year the firm acquired the certificate, so we can also use lagged values of LURC ownership to address this concern.23 In addition to interacting these measures of movings costs with Employ $p^{-}{ }_{j}$, we also show the results controlling for the interaction of Employ $p^{-}{ }^{j t}$ with average firm size in the industry to isolate the effects of land ownership status from other general industry characteristics, in case land ownership and LURC status are correlated with firm size. We also examine a host of other controls below.

The first two columns of Table 4 compare firms that own land and have an LURC against the omitted category of all other firms, both those that are renting and those that own land without an LURC. The coefficient on the interaction with log employment is -0.29 and significant at the 1 percent level, suggesting that indeed firms with LURCs have the largest reduction in bribe rates as predicted employment increases. This is consistent with the prediction of Proposition 2.

To interpret the magnitudes, recall that the overall average reduced form coefficient of increasing employment on reduced corruption from Table 3 is -1.7 . The results in column 1 suggest that the impact is about $17(=0.29 / 1.7)$ percent larger in magnitude for firms with a LURC than those without it.

Columns 3 and 4 examine heterogeneity based on whether the firm owns its land as opposed to renting it. The coefficient on the interaction term is negative, though not statistically significant. As mentioned above, it is not theoretically obvious whether firms that rent or own have more mobility.

Columns 5 and 6 include both sets of interactions. Here, since we have also included the interaction between the firm owning land and employment, the coefficient on the interaction of Firm owns land and has LURC and $\log (E m p l o y)$ is now the additional impact of owning an LURC conditional on owning land, i.e., comparing firms that own land and have a LURC with those that own land and do not have an LURC. This interaction coefficient is negative and significant at the 10 percent level 24

\footnotetext{
${ }^{23}$ Unfortunately, we do not know the year the firm purchased its land, so we cannot do the analogous exercise for land ownership. In Appendix Table 4, we show the results using contemporaneous LURC.

${ }^{24}$ We have also estimated ordered probit reduced form specifications for the three categories of firms: firms that rent the land they operate on, firms that own their land but do not have an LURC, and firms that own their land and have an LURC. Results are presented in Appendix Table 5. The coefficient estimates are consistent with the findings for the linear model in that the most negative impact of economic shocks on the bribe rate is observed for firms that own their land and have an LURC. We run separate ordered probit
} 
Across all six columns in Table 4, the coefficient on the interactions are insensitive to whether we control for firm size interacted with log employment, suggesting that the land ownership and LURC variables are really picking up something about the land characteristics rather than industries with larger or smaller firms.

Nevertheless, possessing an LURC is not randomly assigned, and could be correlated with a variety of other firm characteristics. Indeed, Appendix Table 3 shows that posseessing an LURC is indeed correlated with a variety of other firm characteristics. To examine whether the heterogeneity in impacts we observed in Table 4 are really attributable to the LURC rather than these other correlated characteristics, Table 5 presents several additional robustness checks, controlling for these possible correlates of property rights separately, and then using a propensity score approach to isolate the role of the LURC.

First, one concern is that property rights over land are really measuring overall formality rather than land rights per se. Column 1 of Table 5 controls for a proxy for a firm's degree of formality - the share of registration documents it has - and its interaction with log (Employ). Adjusting for this measure, the interaction coefficient of interest Has $L U R C \times \log ($ Employ) remains significant at the 1 percent level in Panel A and at the 10 percent level in Panel $\mathrm{C}$, and in fact increases in magnitude. In addition, in the comparison of land-owning firms to renting firms in Panel B, the effect of growth on bribes is now statistically significantly larger in magnitude (more negative) for firms that own land. Columns 2 to 7 control for other potentially confounding factors such as whether the firm is a former household firm, whether it is a former state-owned enterprise, whether it is managed by a former government official, whether the government has an ownership stake, premise size, and years of establishment; in each case, the variable and its interaction with $\log (E m p l o y)$ are added to the regression. Across the board, the interaction term with having an LURC remains statistically significant in Panel A. In Panel $\mathrm{C}$ the interaction term is remarkably stable in magnitude across the specifications and is significant at the 10 or 5 percent level in all cases.

Column 8 of Table 5 aggregates all of these control variables into an index by estimating a propensity score to have an LURC based on the seven variables used in columns 1 to 7.25 The propensity to have an LURC and its interaction with $\log ($ Employ) are controlled for in this specification. Reassuringly, the finding that the effect of growth on bribes is stronger for firms with an LURC (better property rights) is robust to this alternative specification

models on the subsamples because the interacted model is computationally infeasible.

${ }^{25}$ As discussed above, Appendix Table 3 shows the coefficients of the propensity score regressions. 
as well. The interaction with LURC is negative and significant at the 1 percent level in Panel A, when the comparison group is all other firms, and negative and significant at the 5 percent level in Panel $\mathrm{C}$, when the comparison group is firms that own land but do not possess an LURC.

\section{Firms operating in multiple provinces}

The PCI data provide a second proxy for firm mobility that we can use to test for heterogeneous effects: having operations in multiple provinces. Of the firms in the sample, 8 percent have operations in at least two provinces. These firms likely have a more credible threat to wholly move elsewhere or simply focus their expansion plans elsewhere, making them more observably mobile to provincial officials.

Table 6 examines heterogeneity based on multi-province operations. Columns 1 and 2 use the number of provinces other than where the firm is headquartered that it operates in. The interaction is negative and significant at the 5 percent level, both with and without controlling for the industry's average firm size. Columns 3 and 4 use instead a dummy variable for operating in at least one other province. The interaction coefficient is -0.36 in column 3 (significant at the 10 percent level) and -0.37 in column 4 (significant at the 5 percent level). The main effect of $\log (E m p l o y)$ in column 3 is -1.85 , so the interaction coefficient implies that having multi-province operations increases the negative effect of growth on the bribe rate by 20 percent.

Table 7 presents the battery of robustness checks for the result that growth decreases the bribe rate for firms with multi-province operations. When including the seven distinct control variables, the coefficient of interest remains stable in magnitude and remains statistically significant in six cases. The exception is the share of registration documents the firm has. The coefficient also loses statistical significance with the propensity-score control variable, but in both of these cases, the point estimate remains negative.

To summarize, our empirical analysis suggests, first, that positive economic shocks reduce corruption, and, second, that corruption falls faster in response to positive economic shocks when firms are more elastic in their location choices. This second finding is seen both when using firms' property rights over their land as a proxy for their relocation costs and when using multi-province operations as a proxy for the ability to relocate. 


\subsection{Alternative models}

Empirical confirmation of several predictions of our model supports the idea that interjurisdictional competition is a mechanism through which economic growth can reduce bribery. However, there are also other potential models that predict a negative correlation of economic growth and the bribe rate. The first and most direct way to distinguish between the inter-jurisdictional model and these other models is that we find that the relationship between growth and bribery is diminished for firms that are less likely to relocate outside their province. This is a direct prediction of inter-jurisdictional competition, but is not predicted by other models.

Nonetheless, it is possible that these heterogenous effects are picking up other firm characteristics besides property rights or multiple locations. Thus, it is important to consider several other possible explanations for the general pattern that economic growth reduces bribes, and to discuss the degree to which our evidence is, or is not, consistent with them.

\section{Product-market competition}

Economic growth could increase competition among firms, and this product market competition affects the amount of rents bureaucrats can capture. If firms have less market power and smaller rents, then bureaucrats may be less able to extract bribes from them. Ades and Di Tella (1999) present empirical evidence that product market competition reduces corruption, for example. To probe the possibility of this mechanism, we test the starting premise that the variation in economic growth that we analyze increases market competition. We regress the Herfindahl index, constructed using employment (our most accurate measure of firm size) from the GSO data, on our instrument. We find that the instrument leads to less, not more, competition, suggesting that the main mechanism through which growth reduces bribery in our context is not increased firm competition (Table 8, column 1) ${ }^{26}$ However, Bliss and Di Tella (1997) present a model in which, counterintuitively, less competition among firms can lead to less bribery; it is possible that this mechanism of reduced competition among firms (higher rents for firms) leading to a reduction in bribe extraction is at play in

\footnotetext{
${ }^{26}$ Another option would be to test for changes in profit margins directly. However, the profit margin data in the GSO is known to be much less reliable than employment (Tran and Dao, 2013), as firms routinely underreport profits to avoid taxes. For example, in the GSO data, 38 percent of firms report a profit margin of less than 1 percent of revenues, with 23 percent of firms reporting 0 profits. Given these reporting issues, the PCI dataset does not ask about profits.
} 
our setting.

\section{Spurious effect of industry-specific bribe crackdowns}

A second possibility we consider is that there are industry-specific crackdowns on bribes. As discussed earlier, this represents the fundamental identification assumption: There are no industry-specific crackdowns on bribes. The strongest evidence in support of our assumption is the institutional structure of Vietnam, which we described in Section 3.1. In addition to this general evidence that bribery is decentralized to the province level in Vietnam, so national industry-level crackdowns are unlikely (recall that our identifying variation is es-

sentially Vietnam-wide growth for an industry), we also undertook a systematic review of the national anti-corruption website, which documents major anti-corruption efforts of the government. Over the study period, only one industry-specific anti-corruption campaign is documented, a crackdown in the construction industry in 2008. Table 8, column 2 shows that the main results are essentially unchanged when we re-run our main specification from column 1 of Table 3, but excluding the construction industry. As the fundamental identification assumption, it is difficult to establish empirically that there are no industry-specific shocks to bribes, but the qualitative evidence points against such an explanation for the patterns we find.

\section{Fixed cost of anti-corruption enforcement}

Another possibility is that there is a layer of oversight over bureaucrats aimed at rooting out corruption, such as an anti-corruption agency. The overseers face a fixed cost of enforcement, so as the total scale of bribery (in levels) goes up, it is easier to detect and punish bribery. Or said differently, it may be easier to detect a larger bribe. If so, then as firms grow, bureaucrats will adjust the bribe rate down.

While this explanation may be at work at the cross-country level, it does not seem to be a key factor explaining the results in this paper. In particular, since most regulatory activities are at the province level, if fixed costs were the main explanation, then the key factor determining bribes would be the overall size of economic activity in the province as a whole, not the size of particular industries.

To test this, column 3 of Table 8 reruns the main regression, but in addition to including predicted log employment in a particular industry, we also include predicted log employment 
in the province as a whole. To do this, we calculate the log of the weighted sum over all industries of employment in the industry in a given year in all provinces excluding province $p$ itself (relative to the average over all years), where the weights represent the share of total employment in province $p$ that comes from industry $j$. Specifically, define the weights for each industry $j$ in province $p$ as:

$$
w_{p j}=\frac{1}{T} \sum_{t} \frac{\text { employment }_{p j t}}{\text { employment }_{p t}}
$$

Then the predicted log employment in province $p$ at time $t$ is:

$$
\text { predicted log employment } \text { et }_{p t}=\log \left(\sum_{j} w_{p j} \frac{\text { employment }_{p^{-} j t}}{\left(\frac{1}{T} \sum_{t} \text { employment }_{p^{-} j t}\right)}\right)
$$

where the $\frac{1}{T} \sum_{t}$ employment $_{p^{-} j t}$ term is a normalization such that the weights to each industry are given eactly by $w_{p j}$. Note that with a single industry $j$ in a province, predicted $\log$ employment $_{p t}$ reduces exactly to our usual right-hand side variable log Employ $p_{p^{-j t}}$.

Using this approach, the evidence in column 3 suggests that, while the point estimate on overall province level predicted log employment ${ }_{p t}$ is negative, the coefficient on industryspecific $\log E_{m p l o p^{-}-j t}$ is unchanged when we include this variable. This suggests that the results are not being driven by aggregate changes in enforcement practices at the province level.

\section{Diminishing returns to bribes}

A final alternative explanation for the main effect we find is that bureaucrats have diminishing marginal utility of income relative to the risk of being caught and going to jail. Thus, as it becomes easier to extract a given amount of bribe revenues, they reduce the rate. The reduced form effect of this mechanism would be similar to a fixed cost of anti-corruption enforcement within each province: A decline in bribes would be driven by aggregate employment in the province, not industry specific employment. The results in column 3 of Table 8 suggest that this is not the entire explanation for our results. 


\section{Summary}

In summary, to the extent we can examine quantitative and qualitative predictions of these alternative models, we do not find that other mechanisms can explain all the facts in the data. It still may well be that these other mechanisms are in operation and explain some of the overall effect of growth on bribery. But, the positive evidence in support of interjurisdictional competition and the limited evidence in support of models suggests that the mechanism we highlight is at least one important factor in why economic growth reduces corruption in Vietnam.

\section{Conclusion}

This paper establishes two empirical facts. The first is that economic growth (as measured by higher employment for a firm or industry) reduces the proportion of firm revenues extracted by government officials as bribes. The second is that the reduction in corruption caused by economic growth is larger in magnitude for firms that can more easily relocate due to stronger property rights over their land. We also find similar evidence of heterogeneous effects using a second measure of the ability to relocate, namely having operations in more than one province.

These two facts map to the two main contributions of the paper. The first is a simple but important empirical contribution: We provide causal evidence on the effect of economic growth on the amount of corruption in an economy. Despite much interest in the relationship between corruption and development, there exists very little credible evidence of a causal relationship. The challenge is finding a way to separate causation from just correlation. We provide rigorous evidence by using subnational variation and an often-used identification strategy based on aggregate-level (national) shocks outside of a subnational region as a source of plausibly exogenous variation in the region.

What makes this identification strategy both possible and plausible is the setting: Vietnam. We make use of a unique data set that collects data from firms on their bribe payments to government officials and is available for several years, samples firms from several industries, and is representative at the province level. In addition, the institutional context of Vietnam makes our key identifying assumption plausible. A limitation of this general class

of aggregate-shock empirical strategies is that there could be reverse causality bias if there 
are aggregate shocks to the outcome (bribes), which in turn affect the independent variable (economic activity). Corruption likely does affect economic activity, but what addresses this concern in our context is that nationwide, industry specific shocks to corruption are unlikely. There is a large body of research in political science showing that corruption is decentralized in Vietnam, and provincial governments independently determine the level of bribes extracted from firms in their jurisdiction. The general framework that we have developed in this paper can also be applied in other countries where a lot of the corruption activities are highly localized, such as China.

Our second contribution is to lay out a mechanism through which economic growth reduces corruption. We model provincial governments' decisions about bribe extraction. Competition among provinces to retain or attract firms is the mechanism that keeps corruption in check. Not surprisingly, then, if a firm is more able to relocate, a government will be more cautious about extracting bribes from it. Less obvious is how a change in economic activity affects corruption. There are offsetting forces. As a firm grows, a given increase in the bribe rate would translate into a larger increase in bribe revenues extracted from the firm. On the other hand, the larger a firm is, the more it would benefit from moving to a different region with a lower bribe rate. We show that under the plausible assumption that a firm's moving costs scale up less than one-for-one with its size, economic growth leads to a decline in the rate of bribe extraction. We also derive the prediction that this effect of economic growth on bribe extraction is larger in magnitude for firms with lower moving costs. Our second empirical fact described above - that the effect of growth on corruption is larger for firms with transferable rights to their land - is consistent with this prediction, suggesting that the mechanism of inter-provincial competition is indeed important in determining the degree of corruption in an economy.

Our results have several implications for understanding the determinants of corruption in developing countries. The finding that growth reduces corruption suggests that corruption might decline naturally as a country grows even without explicit anti-corruption efforts. While the effects we describe here might naturally operate via within-country competition in relatively large, decentralized countries such as Vietnam, one could imagine similar factors might also be at play for small countries, where the competition might be between countries rather than between regions of a given country.

Moreover, the mechanism of inter-jurisdictional competition offers several ways that na- 
tional governments might expedite the decline in corruption. One option involves focused improvements in governance in one region, as suggested by Wei (1999b) and Fisman and Werker (2010), with the idea being that competitive pressure of the type discussed here would lead these improvements to spill over to other regions. More directly tied to our empirical findings, strengthening property rights so that firms can more easily recoup the value of their land if they move would strengthen the competition among jurisdictions and hence the corruption-reducing effect of growth. More generally, reducing any barriers to firm mobility, for example related to business registration, would amplify the negative effect of growth on corruption. The results also highlight a complex interplay between growth and institutions. The fact that economic growth is most successful in reducing corruption when coupled with strong property rights implies a complementarity between policies to strengthen institutions and to promote growth, and a mechanism through which strengthening institutions can be self-reinforcing.

While the focus of this paper is government corruption, it is worth noting the implications for the parallel case of tax rates. Our model implies that economic growth should lead to a reduction in tax rates via the same mechanism of inter-jurisdictional competition, especially for firms that can credibly threaten to relocate. If most firm relocations are within a country, then the prediction is that sub-national (e.g., state) corporate tax rates should decline with economic growth. While we do not have explicit data on sub-national corporate tax rates across countries, it is worth noting that total corpoate taxes are indeed lower as a share of GDP in rich countries than poor countries (Gordon and Li, 2009).

Finally, it is important to note that while we have implemented the idea of economic growth and firm mobility as forces for reducing corruption within a single country, similar ideas could work across countries as well. For example, multinationals face a choice of which countries to locate in or to source their products from. As they grow, it becomes more worthwhile to pay a cost to move to a country with lower corruption, and as long as that cost is concave in firm size, this will lead countries to reduce bribe rates in an attempt to prevent too many firms from switching. This effect will be larger in industries with low switching costs across countries, like textiles, than in industries with high switching costs, such as mining. We leave exploration of these issues for future work. 


\section{References}

Acemoglu, D., And S. Johnson (2005): "Unbundling Institutions," Journal of Political Economy, 113(5), 949-995.

Acemoglu, D., S. Johnson, and J. A. Robinson (2005): "Chapter 6: Institutions as a Fundamental Cause of Long-Run Growth," vol. 1, Part A of Handbook of Economic Growth, pp. $385-472$. Elsevier.

Ades, A., and R. Di Tella (1999): "Rents, Competition, and Corruption," American Economic Review, 89(4), 982-993.

Bartik, T. (1991): Who Benefits from State and Local Economic Development Policies? W.E. Upjohn Institute for Employment Research, Kalamazoo, Michigan.

Blanchard, O. J., and L. F. Katz (1992): "Regional Evolution," Brookings Papers on Economic Activity, 2, 1-75.

Bliss, C., and R. Di Tella (1997): "Does Competition Kill Corruption?," Journal of Political Economy, 105(5), 1001-1023.

Bound, J., And H. Holzer (2000): "Demand Shifts, Population Adjustments, and Labor Market Outcomes During the 1980s," Journal of Labor Economics, 18(1), 20-54.

Burgess, R., M. Hansen, B. A. Olken, P. Potapov, and S. Sieber (2012): "The Political Economy of Deforestation in the Tropics," Quarterly Journal of Economics, 127(4), $1707-1754$.

Cremer, H., and V. Fourgeaud (1995): "Mobility and Redistribution: A Survey," Discussion paper, Université Catholique de Louvain, Center for Operations Research and Econometrics (CORE).

Cung, N. D., P. A. Tuan, B. Van, and D. Dapice (2004): "History or Policy: Why Don’t Northern Provinces Grow Faster?," Discussion paper, United Nations Development Programme.

de Janvry, A., K. Emerick, M. Gonzalez-Navarro, and E. Sadoulet (2012): "Certified to Migrate: Property Rights and Migration in Rural Mexico," Discussion paper, Berkeley.

De Long, J. B., and A. Shleifer (1993): "Princes and Merchants: European City Growth before the Industrial Revolution," Journal of Law and Economics, 36(2), 671702.

De Soto, H. (1989): The Other Path: The Invisible Revolution in the Third World. New York : Harper \& Row.

(2000): The Mystery of Capital: Why Capitalism Triumphs in the West and Fails Everywhere Else. New York : Basic Books. 
Di Tella, R., S. Galiant, and E. Schargrodsky (2007): "The Formation of Beliefs: Evidence from the Allocation of Land Titles to Squatters," The Quarterly Journal of Economics, 122(1), 209-241.

Diamond, R. (2012): "Housing Supply Elasticity and Rent Extraction by State and Local Governments," Discussion paper, Stanford University.

Do, Q.-T., And L. Iyer (2003): "Land Rights and Economic Development : Evidence from Vietnam," Discussion Paper 3120, World Bank, Washington DC.

Epple, D., And T. Romer (1991): "Mobility and Redistribution," Journal of Political Economy, pp. 828-858.

Epple, D., And A. Zelenitz (1981): "The Implications of Competition Among Jurisdictions: Does Tiebout Need Politics?," Journal of Political Economy, pp. 1197-1217.

Fforde, A., And S. De Vylder (1996): From Plan to Market: The Economic Transition in Vietnam. Westview Press Boulder, CO.

Field, E. (2007): "Entitled to Work: Urban Property Rights and Labor Supply in Peru," The Quarterly Journal of Economics, 122(4), 1561-1602.

Fisman, R., AND E. Werker (2010): "Innovations in Governance," vol. 11 of Innovation Policy and the Economy, pp. 79-102. National Bureau of Economic Research.

Galiani, S., and E. Schargrodsky (2010): "Property Rights for the Poor: Effects of Land Titling," Journal of Public Economics, 94(9), 700-729.

Glaeser, E. L., R. La Porta, F. Lopez-de Silanes, and A. Shleifer (2004): "Do Institutions Cause Growth?," Journal of Economic Growth, 9, 271-303.

Goldstein, M., and C. Udry (2008): "The Profits of Power: Land Rights and Agricultural Investment in Ghana," Journal of Political Economy, 116(6), 981-1022.

Gordon, R., And W. Li (2009): "Tax Structures in Developing Countries: Many Puzzles and a Possible Explanation," Journal of Public Economics, 93(7-8), 855- 866.

Gueorguiev, D., And E. Malesky (2011): "Foreign Investment and Bribery: A FirmLevel Analysis of Corruption in Vietnam," Journal of Asian Economics.

Jones, E. (1981): The European Miracle: Environments, Economies and Geopolitics in the History of Europe and Asia. New York: Cambridge University Press.

KIM, A. M. (2004): "A Market Without the 'Right' Property Rights," Economics of Transition, 12(2), 275-305.

Malesky, E. (2008): "Straight Ahead on Red: How Foreign Direct Investment Empowers Subnational Leaders," The Journal of Politics, 70(1), 97-119. 
(2011): "The Vietnam Provincial Competitiveness Index: Measuring Economic Governance for Private Sector Development," Discussion paper, US AIDs Vietnam Competitiveness Initiative and Vietnam Chamber of Commerce and Industry.

Mauro, P. (1995): "Corruption and Growth," Quarterly Journal of Economics, 110(3), $681-712$.

Menes, R. (2006): "Limiting the Reach of the Grabbing Hand. Graft and Growth in American Cities, 1880 to 1930," in Corruption and Reform: Lessons from America's Economic History, pp. 63-94. University of Chicago Press.

Meyer, K. E., AND H. V. NGuYen (2005): "Foreign Investment Strategies and Sub-national Institutions in Emerging Markets: Evidence from Vietnam," Journal of Management Studies, 42(1), 63-93.

Mocan, N. (2004): "What Determines Corruption? International Evidence From Micro Data," National Bureau of Economic Research Working Paper.

North, D. . (1991): "Institutions," The Journal of Economic Perspectives, 5(1), 97-112.

Olson, M. (2000): Power and Prosperity: Outgrowing Capitalist and Communist Dictatorships. New York: Basic Books.

Riedel, J., And W. Turley (1999): The Politics and Economics of Transition to an Open Market Economy in Viet Nam, no. 152. OECD.

Rose-Ackerman, S. (1978): Corruption: A Study in Political Economy. Academic Press.

Shleifer, A., And R. W. Vishny (1993): "Corruption," Quarterly Journal of Economics, 108(3).

Svensson, J. (2003): "Who Must Pay Bribes and how Much? Evidence from a Cross Section of Firms," Quarterly Journal of Economics, 118(1), 207-230.

Tran, A., And N. Dao (2013): "The Darker Side of Private Ownership: Tax Evasion in Vietnamese Privatized Firms," Working paper, Indiana University.

Tran, T. B., R. Q. Grafton, and T. Kompas (2009): "Institutions Matter: The Case of Vietnam," Journal of Socio-Economics, 38(1), 1-12.

Transparency International (2011): "Global Corruption Barometer 2010/2011," Report.

Treisman, D. (2000): "The Causes of Corruption: A Cross-National Study," Journal of Public Economics, 76(3), 399 - 457.

Treisman, D. (2007): "What Have We Learned about the Causes of Corruption from Ten Years of Cross-National Empirical Research?," Annual Review of Political Science, 10, 211-244. 
VAlsecchi, M. (2011): "Land Property Rights and Migration: Evidence from Mexico," Discussion paper, University of Gothenburg.

Vasavakul, T. (2008): "Recrafting State Identity: Corruption and Anti-Corruption in Vietnamese State: Implications for Vietnam and the Region," Discussion paper, Vietnam Workshop, City University of Hong Kong, August 21-22.

WeI, S.-J. (1999a): "Corruption in Economic Development: Beneficial Grease, Minor Annoyance, or Major Obstacle?," Policy Research Working Paper 2048, World Bank.

(1999b): "Special Governance Zone: A Practical Entry-Point for a Winnable AntiCorruption Program.," Discussion paper, Brookings Institution.

Weingast, B. R. (1995): "The Economic Role of Political Institutions: Market-Preserving Federalism and Economic Development," Journal of Law, Economics, and Organization, pp. $1-31$.

Wildasin, D. (2003): "Fiscal Competition in Space and Time," Journal of Public Economics, 87(11), 2571-2588.

Wilson, J. (1986): "A Theory of Interregional Tax Competition," Journal of Urban Economics, 19(3), 296-315. 
Figure 1: Cross-Country Relationship Between GDP and Corruption

Panel A. Transparency International Corruption Index (2005)

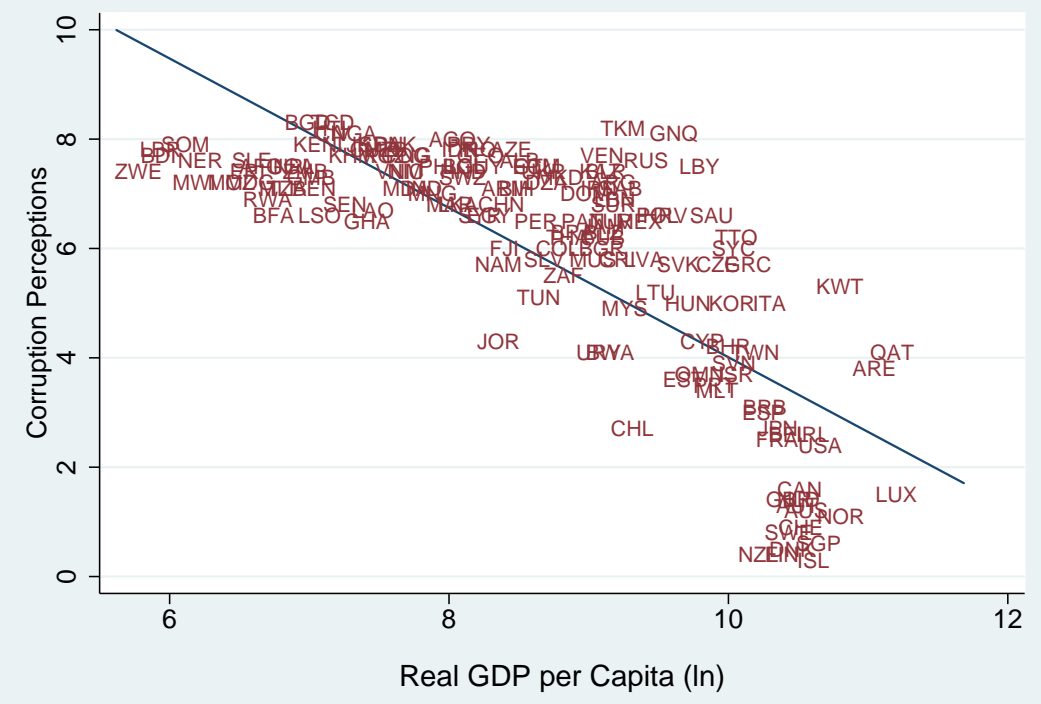

Panel B. World Bank Control of Corruption (2005)

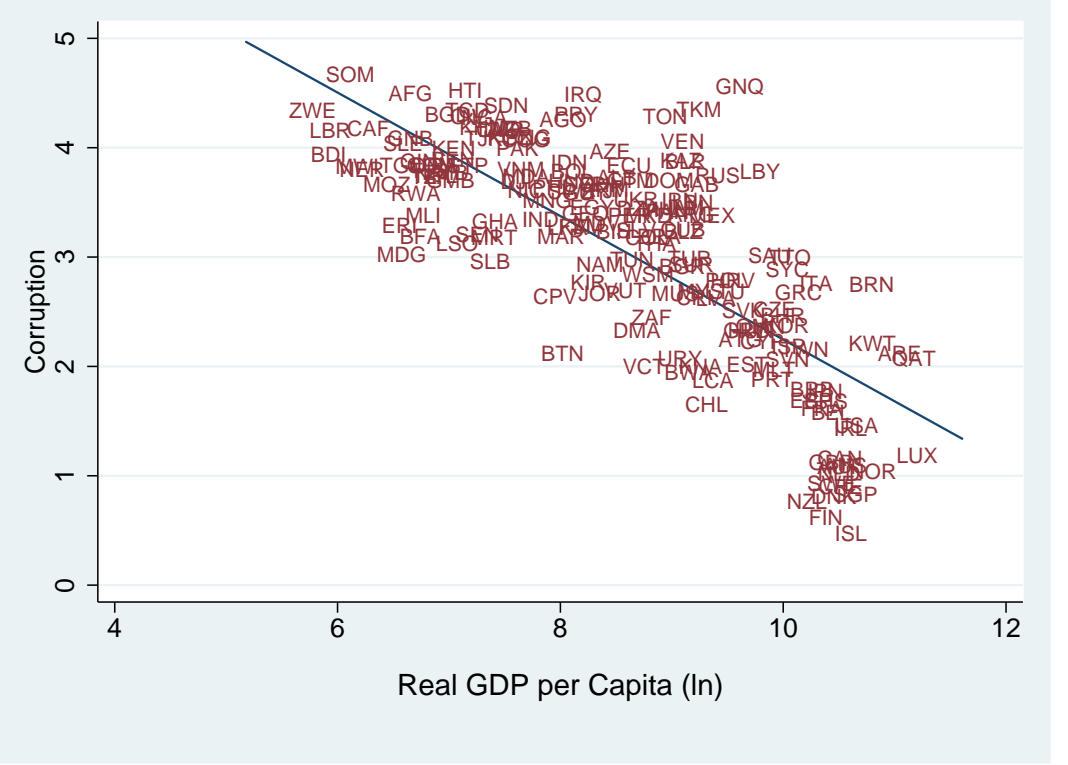

In Panel A, the Corruption Perception Index (CPI) defines corruption as the abuse of public office for private gain. The CPI Score measures perceptions of the degree of corruption as seen by business people, risk analysts, and the general public and ranges between 10 (highly corrupt) and 0 (highly clean). In Panel B, Control of Corruption measures perceptions of corruption, conventionally defined as the exercise of public power for private gain. It ranges between 5 (highly corrupt) and 0 (highly clean). In both panels, the x-axis is the log of PPP Converted GDP Per Capita (Chain Series), at 2005 constant prices. 
Figure 2: Relationship Between GDP and Corruption Using Survey Data from Firms

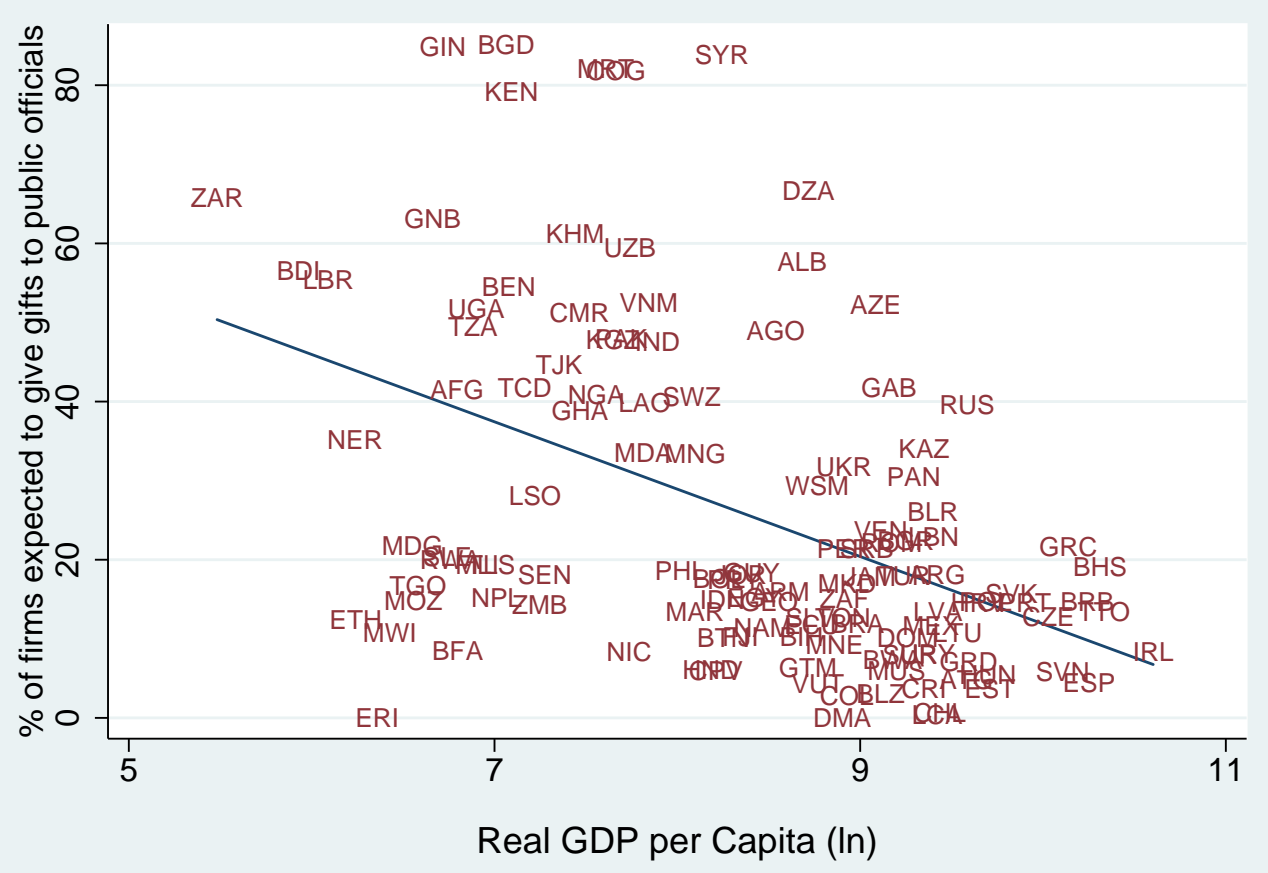

This figure plots the percentage of firms who expect to give gifts to public officials to get things done for 122 countries in the World Bank Enterprise Survey. For each country, we use the year that the country is most recently surveyed. The x-axis is the log of PPP-adjusted GDP per capita (Chain Series), at 2005 constant prices. 
Figure 3: Time Trend in Bribes and GDP in Vietnam

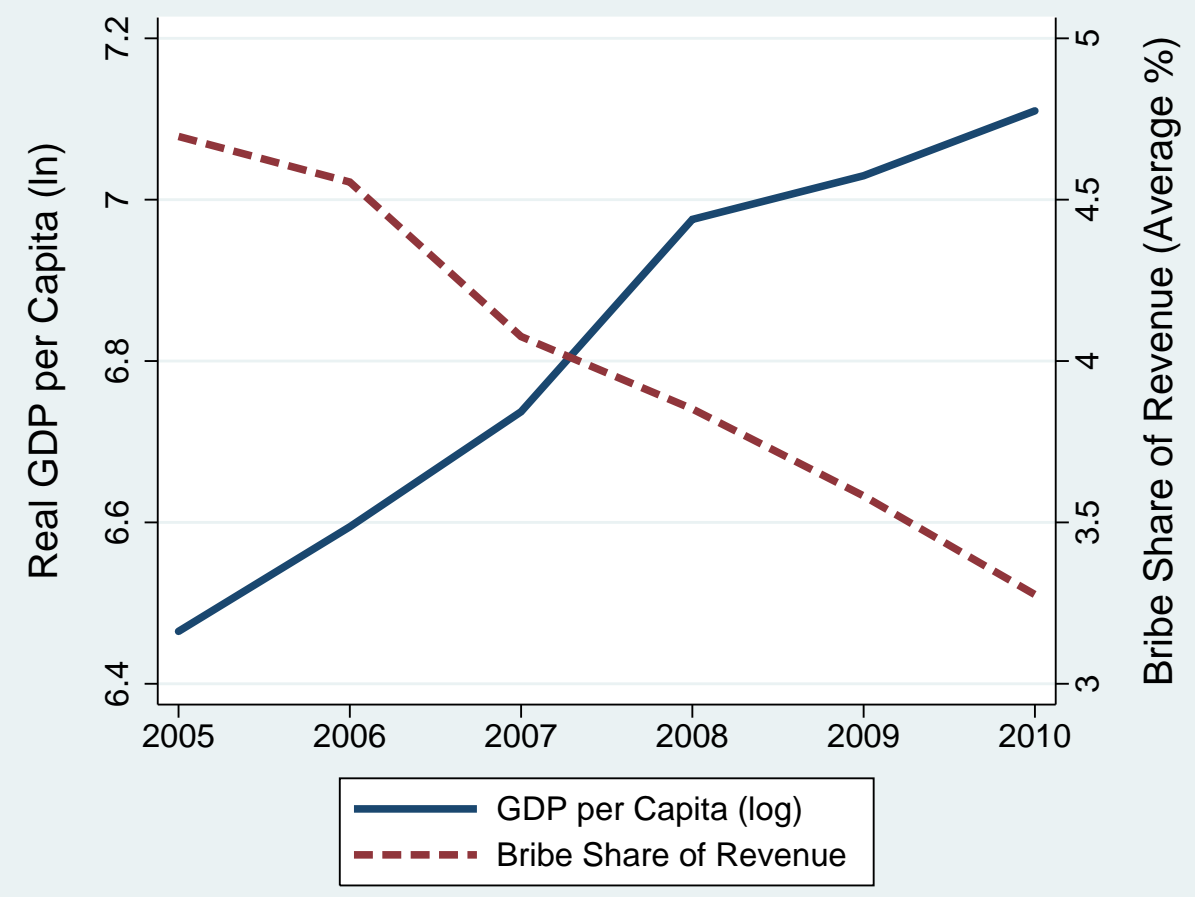

This figure plots real GDP per capita and the average amount of bribe as a share of revenue paid by firms in Vietnam from 2005 to 2010. The bribe share variable is averaged across all firms surveyed in the PCI for the corresponding year. 
Figure 4: Average Annual GDP Growth by Province in Vietnam (2006-2010)

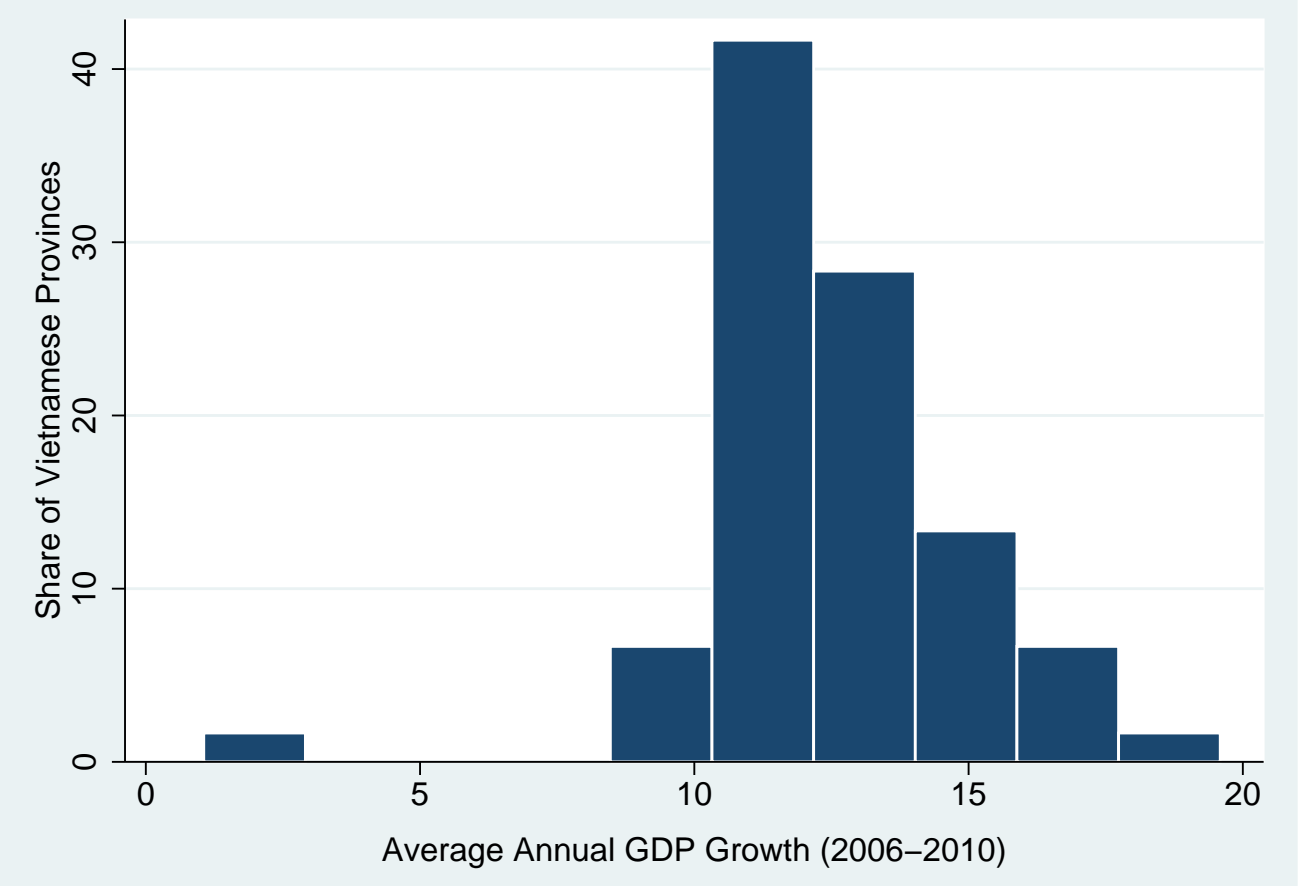

This figure plots the distribution of average annual GDP growth across provinces in Vietnam from 2006 to 2010 . We have excluded provinces that reported implausibly high growth rate over this period (over 20 percent) as these numbers are very much likely overstated. 
Figure 5: Variation in Corruption across Provinces in Vietnam

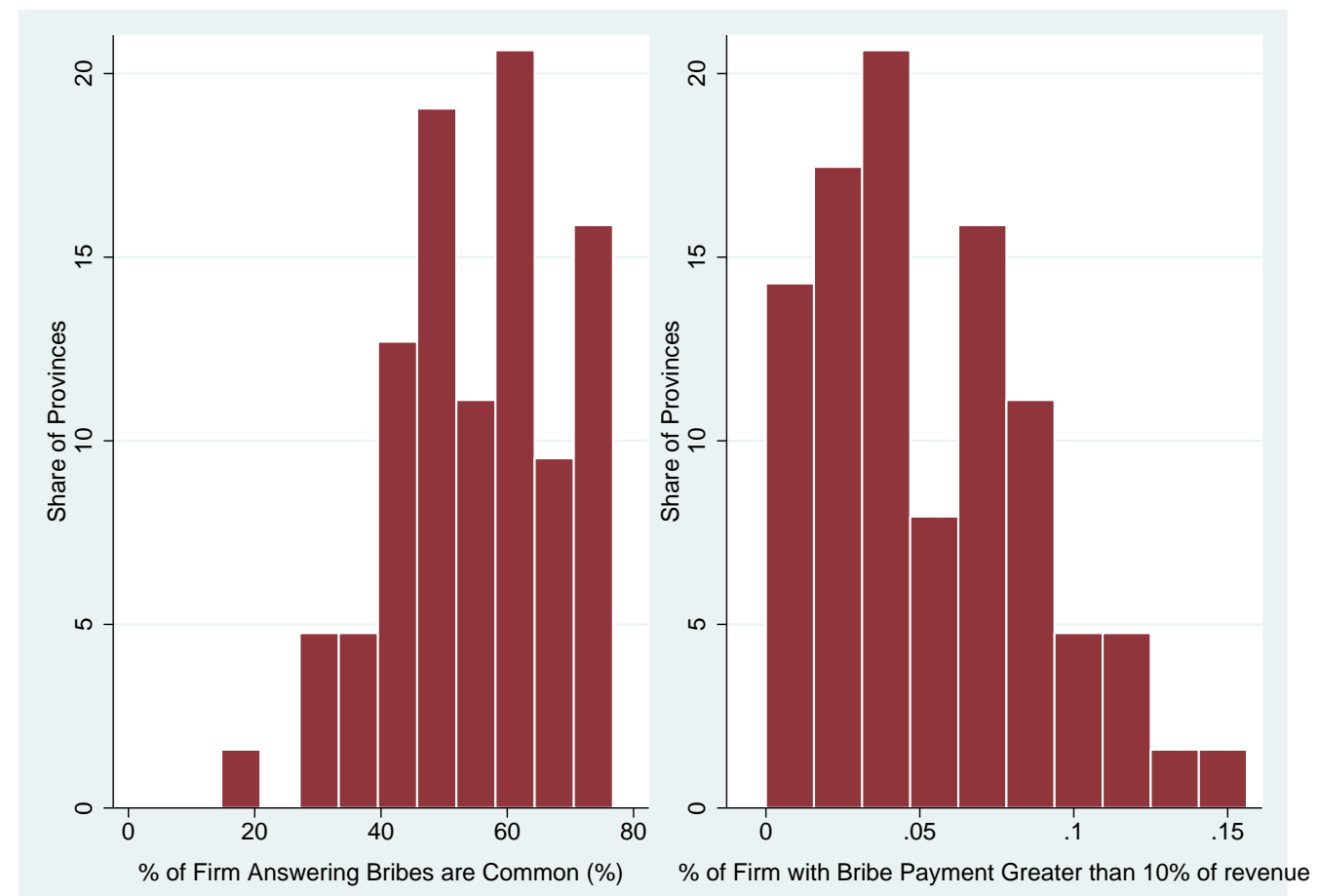

This figure plots the distribution of corruption across provinces in Vietnam, using data from the 2010 PCI survey. The bribe variables are averages across all firms surveyed within a province. The variable in the left panel is a dummy that equals 1 if the firm responds "strongly agree" or "agree" to the following statement: "It's common for firms like mine to pay informal charges." The variable in the right panel is a dummy that equals 1 if the firm paid more than 10 percent of revenues as bribes to public officials. 
Figure 6: Cross-Sectional Relationship Between Bribe Rate and Firm Employment

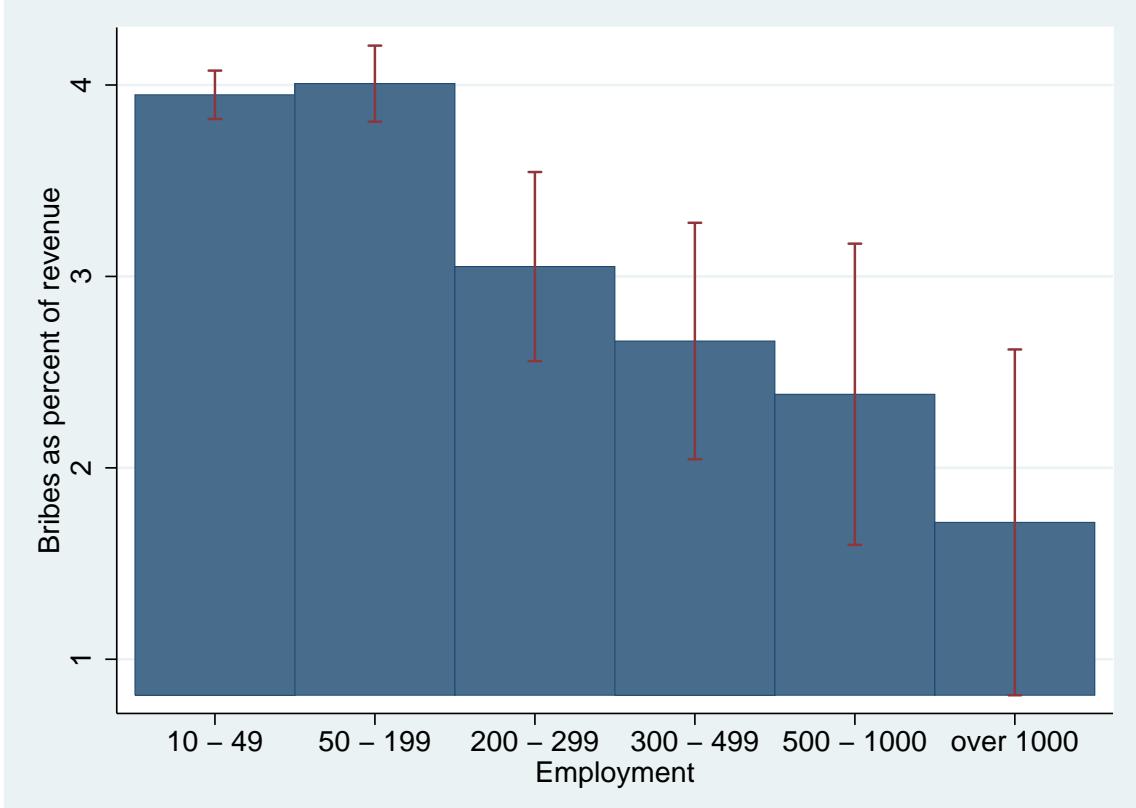

This figure plots the mean bribe rate as a percent of revenue for each employment size category as well as the 95 percent confidence interval. 
Table 1: Summary Statistics of Firms

\begin{tabular}{|c|c|c|c|c|}
\hline & Observations & Median & Mean & Std Dev \\
\hline Bribes as percentage of revenue $(\%)$ & 13160 & 1.5 & 3.8 & 5.671 \\
\hline Years since establishment & 12846 & 4 & 5.505 & 6.317 \\
\hline Number of employees (PCI) & 12011 & 21 & 94.939 & 248.869 \\
\hline Mean employment (GSO, mean for industry-year-province level) & 13160 & 23.776 & 36.753 & 33.868 \\
\hline Log total employment (GSO, aggregate for industry-year-province) & 13160 & 9.091 & 9.01 & 1.866 \\
\hline Log of business premise size (hectare) & 6397 & 6.879 & 7.073 & 2.204 \\
\hline Land ownership (dummy) & 13160 & 1 & .726 & .446 \\
\hline Land use right certificate (dummy) & 12632 & 1 & .575 & .494 \\
\hline Land ownership without land use right certificate (dummy) & 12632 & 0 & .139 & .346 \\
\hline Number of other provinces in which firm operates & 13063 & 0 & .387 & 1.021 \\
\hline Firm currently operates in more than one province (dummy) & 13160 & 0 & .082 & .275 \\
\hline Share of registration documents held & 10411 & .167 & .248 & .286 \\
\hline Former household firm (dummy) & 13158 & 1 & .579 & .494 \\
\hline Former SOE (dummy) & 13158 & 0 & .09 & .286 \\
\hline Owner is a government official (dummy) & 13158 & 0 & .133 & .34 \\
\hline Government holds positive share (dummy) & 13158 & 0 & .04 & .196 \\
\hline
\end{tabular}

Note: Each observation is a firm, and we pool the sample of firms over all years from 2006 to 2010. The PCI firms in our sample are those with valid industry and bribe payment data and whose province-industry-year is represented in the GSO data. The summary statistics reported in this table are for the 13,160 firms that meet this sample inclusion criterion. Bribes as percentage of revenue (PCI): This is a 7-point categorical variable drawn from question D6 of the annual PCI survey. Respondents answered within ranges: 1) 0\%;2) less than 1\%;3) 1-2\%;4) 2-10\%; 5) 10-20\%;6) 20-30\%; 7) over $30 \%$. We recode each category with the corresponding cell mean with over $30 \%$ recoded as $35 \%$. Years since establishment (PCI): Continuous variable that subtracts year of establishment from the year the firm completed the survey (2006 to 2010). Establishment only captures when the firm began doing business and has no legal connotation. A follow-up question asks when a firm registered as a formal business. Number of employees (PCI): This variable is categorical in PCI: for example, 10-49, 50-199, etc. We recode each category with the corresponding empirical cell mean in GSO. Mean employment (GSO, mean for industry-year-province level): Continuous measure collected in the GSO Enterprise Census. Log total employment (GSO, aggregate for industry-year-province): Continuous measure collected in the GSO Enterprise Census. Log of business premise size (hectares) (PCI): Continuous measure collected in only the 2009 to 2011 surveys. Land ownership (dummy) (PCI): Dichotomous variable measuring whether a firm purchased (=1) or leases $(=0)$ its main business premises. Land use right certificate (LURC, dummy) (PCI): Dichotomous variable measuring whether a firm possesses an LURC for its main business premises. Land ownership without land use right certificate (dummy) (PCI): Dichotomous variable, calculated from questions about whether a firm owns land and whether it has a LURC for that land. Number of other provinces in which firm operates (PCI): Count variable calculated from firm's response to a question asking it to record all provinces and national-level cities in which it has operations or branch offices, outside of its headquarters location. Firm currently operates in more than one province (dummy) (PCI): Dichotomous variable for whether firm listed operations in at least one province outside the province with its main headquarters. Share of registration documents held: Based on the following question: "In addition to the certificate of business registration, your business may need additional permits or business to be fully legal (e.g. mining licenses....). How many of these documents were required for your firm?" Variable defined as the number of registration documents held by the firm divided by the $95 \%$ percentile of the firm's industry (a proxy for formality). Former household firm (dummy) (PCI): Dichotomous variable for whether the firm operated as an informal business based on household premises before formal registration. Former SOE (dummy) (PCI): Based on questions asking whether the firm is a privatized former State Owned Enterprise (SOE). Equals 1 if the firm is either a locally or centrally managed SOE. Owner is a former government official (dummy) (PCI): Based on question asking whether the owner of the private enterprise is a former government official, army office, or SOE manager. Government holds a positive share (dummy) (PCI): Based on question asking whether shares of the firm are held by local or central government officials. 
Table 2: First Stage Results

\begin{tabular}{lc}
\hline \hline & $\begin{array}{c}\text { Dep. var.: Log total employment } \\
\text { (own-province-industry-year level) }\end{array}$ \\
\cline { 2 - 2 } $\begin{array}{l}\text { Log total employment } \\
\text { (at industry-year level, excluding own province) }\end{array}$ & $\begin{array}{c}0.724^{* * *} \\
\text { Observations }\end{array}$ \\
& 3873 \\
Province-industry and year fixed effects & \\
\hline Note: Each observation is a province-industry-year. The dependent variable is log total employment in the \\
province-industry-year. The independent variable is log total employment of the same industry-year in all \\
provinces other than own. Both variables are calculated using the GSO Enterprise Survey data. Industry \\
refers to an ISIC alphabetical industry code. The regression controls for province-industry and year fixed \\
effects. Standard errors are clustered at the province level. *** implies significance at 0.01 level, ${ }^{* *} 0.5,{ }^{*} 0.1$.
\end{tabular}


Table 3: Effect of Economic Performance on Bribes

Dependent variable: Firm's bribe payment as percentage of revenue

\begin{tabular}{|c|c|c|c|}
\hline & $\begin{array}{c}(1) \\
\text { RF: OLS }\end{array}$ & $\begin{array}{c}(2) \\
\text { RF: Ordered Probit }\end{array}$ & $\begin{array}{l}\text { (3) } \\
\text { IV }\end{array}$ \\
\hline $\begin{array}{l}\text { Log total employment } \\
\text { (at industry-year level, excluding own province) }\end{array}$ & $\begin{array}{c}-1.723^{* *} \\
(0.764)\end{array}$ & $\begin{array}{c}-0.275^{* *} \\
(0.131)\end{array}$ & \\
\hline $\begin{array}{l}\text { Log total employment } \\
\text { (own-province-industry-year level) }\end{array}$ & & & $\begin{array}{c}-2.302^{* *} \\
(1.004)\end{array}$ \\
\hline Observations & 13160 & 13160 & 13160 \\
\hline Province-industry and year fixed effects & $\checkmark$ & $\checkmark$ & $\checkmark$ \\
\hline
\end{tabular}


Table 4: Heterogeneous Effects Based on Firms' Property Rights

Dependent variable: Firm's bribe payment as percentage of revenue

\begin{tabular}{|c|c|c|c|c|c|c|}
\hline & $\overline{(1)}$ & $\overline{(2)}$ & $\overline{(3)}$ & $\overline{(4)}$ & $(5)$ & $(6)$ \\
\hline $\begin{array}{l}\text { Log total employment (at industry-year level, } \\
\text { excluding own province) }\end{array}$ & $\begin{array}{l}-1.583^{*} \\
(0.798)\end{array}$ & $\begin{array}{l}7.914 \\
(5.540)\end{array}$ & $\begin{array}{c}-1.626^{* *} \\
(0.751)\end{array}$ & $\begin{array}{c}6.666 \\
(4.920)\end{array}$ & $\begin{array}{c}-1.598^{* *} \\
(0.785)\end{array}$ & $\begin{array}{l}7.730 \\
(5.579)\end{array}$ \\
\hline Firm owns land and has LURC & $\begin{array}{c}3.891^{* * *} \\
(1.426)\end{array}$ & $\begin{array}{c}3.818^{* * *} \\
(1.417)\end{array}$ & & & $\begin{array}{c}2.393 \\
(1.574)\end{array}$ & $\begin{array}{c}2.349 \\
(1.580)\end{array}$ \\
\hline Firm owns land and has LURC X $\log$ (Employ) & $\begin{array}{c}-0.291^{* * *} \\
(0.104)\end{array}$ & $\begin{array}{c}-0.286^{* * *} \\
(0.103)\end{array}$ & & & $\begin{array}{l}-0.206^{*} \\
(0.115)\end{array}$ & $\begin{array}{r}-0.203^{*} \\
(0.116)\end{array}$ \\
\hline Firm owns its land & & & $\begin{array}{l}2.751^{*} \\
(1.564)\end{array}$ & $\begin{array}{l}2.705^{*} \\
(1.550)\end{array}$ & $\begin{array}{c}2.518 \\
(2.024)\end{array}$ & $\begin{array}{l}2.469 \\
(2.005)\end{array}$ \\
\hline Firm owns its land $\mathrm{X} \log$ (Employ) & & & $\begin{array}{l}-0.186 \\
(0.116)\end{array}$ & $\begin{array}{l}-0.183 \\
(0.115)\end{array}$ & $\begin{array}{l}-0.139 \\
(0.152)\end{array}$ & $\begin{array}{l}-0.136 \\
(0.151)\end{array}$ \\
\hline Observations & 11486 & 11486 & 13160 & 13160 & 11486 & 11486 \\
\hline Contr & $\mathrm{NO}$ & YES & NO & YES & $\mathrm{NO}$ & YES \\
\hline Province-industry and year fixed effects & $\checkmark$ & $\checkmark$ & $\checkmark$ & $\checkmark$ & $\checkmark$ & $\checkmark$ \\
\hline
\end{tabular}

Note: The interaction term is the product of log total employment of the same industry-year group in all provinces other than own and firm-level property rights variables. Column (2), (4) and (6) control for average firm size in the industry. All regressions control for province-industry and year fixed effects. Standard errors are clustered at the province level. ${ }^{* * *}$ implies significance at 0.01 level, ${ }^{* *} 0.5,{ }^{*} 0.1$. 
Table 5: Robustness Check: Heterogeneous Effects Based on Firms' Property Rights

Dependent variable: Firm's bribe payment as percentage of revenue

\begin{tabular}{|c|c|c|c|c|c|c|c|c|}
\hline & $(1)$ & $(2)$ & $(3)$ & $(4)$ & $(5)$ & $(6)$ & $(7)$ & $(8)$ \\
\hline & $\begin{array}{c}\text { share of Registration } \\
\text { documents held }\end{array}$ & $\begin{array}{l}\text { former } \\
\text { HH firm }\end{array}$ & $\begin{array}{l}\text { former } \\
\text { SOE }\end{array}$ & $\begin{array}{l}\text { government } \\
\text { official }\end{array}$ & $\begin{array}{l}\text { government } \\
\text { share }\end{array}$ & $\begin{array}{l}\text { premise } \\
\text { size }\end{array}$ & $\begin{array}{c}\text { years of } \\
\text { establishment }\end{array}$ & $\begin{array}{l}\text { propensity } \\
\text { score }\end{array}$ \\
\hline \multicolumn{9}{|l|}{ Panel A. LURC } \\
\hline $\begin{array}{l}\text { Log total employment (at industry-year } \\
\text { level, excluding own province) }\end{array}$ & $\begin{array}{c}7.691 \\
(6.067)\end{array}$ & $\begin{array}{c}7.733 \\
(5.481)\end{array}$ & $\begin{array}{c}7.624 \\
(5.521)\end{array}$ & $\begin{array}{c}8.579 \\
(5.642)\end{array}$ & $\begin{array}{c}7.851 \\
(5.596)\end{array}$ & $\begin{array}{c}6.746 \\
(5.362)\end{array}$ & $\begin{array}{c}9.107 \\
(5.662)\end{array}$ & $\begin{array}{c}9.732 \\
(6.113)\end{array}$ \\
\hline Firm owns land and has LURC & $\begin{array}{c}4.484^{* * *} \\
(1.577)\end{array}$ & $\begin{array}{c}3.851^{* * *} \\
(1.423)\end{array}$ & $\begin{array}{l}3.980^{* *} \\
(1.514)\end{array}$ & $\begin{array}{c}3.674^{* * *} \\
(1.369)\end{array}$ & $\begin{array}{c}3.822^{* * *} \\
(1.423)\end{array}$ & $\begin{array}{c}4.613^{* * *} \\
(1.528)\end{array}$ & $\begin{array}{l}4.113^{* *} \\
(1.647)\end{array}$ & $\begin{array}{l}5.424^{* *} \\
(2.067)\end{array}$ \\
\hline Firm owns land and has LURC X $\log$ (Employ) & $\begin{array}{c}-0.338^{* * *} \\
(0.115)\end{array}$ & $\begin{array}{c}-0.289^{* * *} \\
(0.104)\end{array}$ & $\begin{array}{c}-0.295^{* * *} \\
(0.110)\end{array}$ & $\begin{array}{c}-0.275^{* * *} \\
(0.100)\end{array}$ & $\begin{array}{c}-0.286^{* * *} \\
(0.104)\end{array}$ & $\begin{array}{c}-0.344^{* * *} \\
(0.110)\end{array}$ & $\begin{array}{c}-0.307^{* *} \\
(0.120)\end{array}$ & $\begin{array}{c}-0.407^{* * *} \\
(0.150)\end{array}$ \\
\hline Observations & 9262 & 11484 & 11484 & 11484 & 11484 & 10611 & 11222 & 8456 \\
\hline \multicolumn{9}{|l|}{ Panel B. Land Ownership } \\
\hline $\begin{array}{l}\text { Log total employment (at industry-year level, } \\
\text { excluding own province) }\end{array}$ & $\begin{array}{c}6.981 \\
(5.685)\end{array}$ & $\begin{array}{c}6.517 \\
(4.863)\end{array}$ & $\begin{array}{c}6.444 \\
(4.900)\end{array}$ & $\begin{array}{l}7.121 \\
(5.008)\end{array}$ & $\begin{array}{c}6.634 \\
(4.935)\end{array}$ & $\begin{array}{c}6.514 \\
(4.797)\end{array}$ & $\begin{array}{l}7.455 \\
(5.048)\end{array}$ & $\begin{array}{l}8.494 \\
(5.707)\end{array}$ \\
\hline Firm owns its land & $\begin{array}{l}3.741^{* *} \\
(1.549)\end{array}$ & $\begin{array}{l}2.689^{*} \\
(1.564)\end{array}$ & $\begin{array}{l}2.756^{*} \\
(1.546)\end{array}$ & $\begin{array}{l}2.639^{*} \\
(1.517)\end{array}$ & $\begin{array}{l}2.702^{*} \\
(1.551)\end{array}$ & $\begin{array}{l}2.949^{*} \\
(1.626)\end{array}$ & $\begin{array}{l}3.018^{*} \\
(1.655)\end{array}$ & $\begin{array}{l}3.970^{* *} \\
(1.834)\end{array}$ \\
\hline Firm owns its land $\mathrm{X} \log$ (Employ) & $\begin{array}{c}-0.270^{* *} \\
(0.115)\end{array}$ & $\begin{array}{l}-0.185 \\
(0.116)\end{array}$ & $\begin{array}{l}-0.187 \\
(0.115)\end{array}$ & $\begin{array}{l}-0.178 \\
(0.113)\end{array}$ & $\begin{array}{l}-0.183 \\
(0.115)\end{array}$ & $\begin{array}{l}-0.198 \\
(0.121)\end{array}$ & $\begin{array}{l}-0.206^{*} \\
(0.122)\end{array}$ & $\begin{array}{c}-0.288^{* *} \\
(0.136)\end{array}$ \\
\hline Observations & 10411 & 13158 & 13158 & 13158 & 13158 & 12027 & 12846 & 9418 \\
\hline \multicolumn{9}{|l|}{ Panel C. Land Ownership and LURC } \\
\hline $\begin{array}{l}\text { Log total employment (at industry-year level, } \\
\text { excluding own province) }\end{array}$ & $\begin{array}{c}7.471 \\
(6.046)\end{array}$ & $\begin{array}{l}7.594 \\
(5.524)\end{array}$ & $\begin{array}{l}7.474 \\
(5.559)\end{array}$ & $\begin{array}{l}8.400 \\
(5.685)\end{array}$ & $\begin{array}{l}7.683 \\
(5.630)\end{array}$ & $\begin{array}{c}6.634 \\
(5.386)\end{array}$ & $\begin{array}{l}8.897 \\
(5.695)\end{array}$ & $\begin{array}{l}9.138 \\
(6.107)\end{array}$ \\
\hline Firm owns its land & $\begin{array}{l}3.371^{*} \\
(1.844)\end{array}$ & $\begin{array}{c}2.438 \\
(2.000)\end{array}$ & $\begin{array}{c}2.449 \\
(1.954)\end{array}$ & $\begin{array}{c}2.482 \\
(1.976)\end{array}$ & $\begin{array}{c}2.480 \\
(2.011)\end{array}$ & $\begin{array}{l}1.953 \\
(2.074)\end{array}$ & $\begin{array}{c}2.794 \\
(2.027)\end{array}$ & $\begin{array}{l}2.881 \\
(2.170)\end{array}$ \\
\hline Firm owns its land X $\log$ (Employ) & $\begin{array}{l}-0.223 \\
(0.138)\end{array}$ & $\begin{array}{l}-0.137 \\
(0.150)\end{array}$ & $\begin{array}{l}-0.137 \\
(0.147)\end{array}$ & $\begin{array}{l}-0.136 \\
(0.148)\end{array}$ & $\begin{array}{l}-0.137 \\
(0.151)\end{array}$ & $\begin{array}{l}-0.093 \\
(0.156)\end{array}$ & $\begin{array}{l}-0.160 \\
(0.152)\end{array}$ & $\begin{array}{l}-0.188 \\
(0.162)\end{array}$ \\
\hline Firm owns land and has LURC & $\begin{array}{c}2.571 \\
(1.687)\end{array}$ & $\begin{array}{c}2.401 \\
(1.543)\end{array}$ & $\begin{array}{c}2.507 \\
(1.639)\end{array}$ & $\begin{array}{c}2.197 \\
(1.562)\end{array}$ & $\begin{array}{c}2.349 \\
(1.585)\end{array}$ & $\begin{array}{l}3.425^{* *} \\
(1.657)\end{array}$ & $\begin{array}{c}2.438 \\
(1.710)\end{array}$ & $\begin{array}{l}3.887^{*} \\
(2.046)\end{array}$ \\
\hline Firm owns land and has LURC X log(Employ) & $\begin{array}{c}-0.211^{*} \\
(0.122)\end{array}$ & $\begin{array}{c}-0.206^{*} \\
(0.113)\end{array}$ & $\begin{array}{c}-0.211^{*} \\
(0.120)\end{array}$ & $\begin{array}{c}-0.192^{*} \\
(0.114)\end{array}$ & $\begin{array}{c}-0.202^{*} \\
(0.116)\end{array}$ & $\begin{array}{c}-0.285^{* *} \\
(0.120)\end{array}$ & $\begin{array}{l}-0.210^{*} \\
(0.125)\end{array}$ & $\begin{array}{c}-0.306 * * \\
(0.147)\end{array}$ \\
\hline Observations & 9262 & 11484 & 11484 & 11484 & 11484 & 10611 & 11222 & 8456 \\
\hline Control for average firm size $\mathrm{X} \log$ (Employ) & YES & YES & YES & YES & YES & YES & YES & YES \\
\hline Province-industry and year fixed effects & $\checkmark$ & $\checkmark$ & $\checkmark$ & $\checkmark$ & $\checkmark$ & $\checkmark$ & $\checkmark$ & $\checkmark$ \\
\hline
\end{tabular}

Note: Column (1) to (7) controls for the following explanatory variables and their interactions with log total employment of the same industry-year group in all provinces other than own: share of registration documents held, former household firm (dummy), former SOE (dummy), owner being a government official (dummy), government holding positive share (dummy), log of business premise size, firm's age. Column (8) controls for the propensity score. All regressions control for province-industry and year fixed effects. Standard errors are clustered at the province level. *** implies significance at 0.01 level, $* * 0.5, * 0.1$. 
Table 6: Heterogeneous Effects Based on Firms' Operation Locations

Dependent variable: Firm's bribe payment as percentage of revenue

\begin{tabular}{|c|c|c|c|c|}
\hline & $(1)$ & $\overline{(2)}$ & $\overline{(2)}$ & $(4)$ \\
\hline Log total employment (at industry-year level, excluding own province) & $\begin{array}{c}-1.911^{* *} \\
(0.768)\end{array}$ & $\begin{array}{c}6.952 \\
(4.846)\end{array}$ & $\begin{array}{c}-1.854^{* *} \\
(0.759)\end{array}$ & $\begin{array}{c}6.802 \\
(4.862)\end{array}$ \\
\hline Number of other provinces in which firm operates & $\begin{array}{c}1.306^{* *} \\
(0.495)\end{array}$ & $\begin{array}{c}1.326^{* *} \\
(0.497)\end{array}$ & & \\
\hline Number of other provinces in which firm operates $\mathrm{X} \log$ (Employ) & $\begin{array}{c}-0.083^{* *} \\
(0.037)\end{array}$ & $\begin{array}{c}-0.085^{* *} \\
(0.037)\end{array}$ & & \\
\hline Firm currently operates in more than one province & & & $\begin{array}{c}5.438^{* *} \\
(2.479)\end{array}$ & $\begin{array}{c}5.531^{* *} \\
(2.475)\end{array}$ \\
\hline Firm currently operates in more than one province $\mathrm{X} \log ($ Employ) & & & $\begin{array}{c}-0.364^{*} \\
(0.185)\end{array}$ & $\begin{array}{c}-0.371^{* *} \\
(0.184)\end{array}$ \\
\hline Observations & 13063 & 13063 & 13160 & 13160 \\
\hline Control for average firm size $\mathrm{X} \log ($ Employ $)$ & $\mathrm{NO}$ & YES & NO & YES \\
\hline Province-industry and year fixed effects & $\checkmark$ & $\checkmark$ & $\checkmark$ & $\checkmark$ \\
\hline
\end{tabular}

Note: The interaction term is the product of log total employment of the same industry-year group in all provinces other than own and firm-level operation location variables. Column (2) and (4) control for average firm size in the industry. All regressions control for province-industry and year fixed effects. Standard errors are clustered at the province level. $* * *$ implies significance at 0.01 level, $* * 0.5, * 0.1$. 
Table 7: Robustness Check: Heterogeneous Effects Based on Firms' Operation Locations

Dependent variable: Firm's bribe payment as percentage of revenue

\begin{tabular}{|c|c|c|c|c|c|c|c|c|}
\hline & (1) & $\overline{(2)}$ & $(3)$ & $(4)$ & $(5)$ & $(6)$ & $(7)$ & $(8)$ \\
\hline & $\begin{array}{l}\text { share of registration } \\
\text { documents held }\end{array}$ & $\begin{array}{l}\text { former } \\
\text { HH firm }\end{array}$ & $\begin{array}{l}\text { former } \\
\text { SOE }\end{array}$ & $\begin{array}{l}\text { government } \\
\text { official }\end{array}$ & $\begin{array}{l}\text { government } \\
\text { share }\end{array}$ & $\begin{array}{l}\text { premise } \\
\text { size }\end{array}$ & $\begin{array}{c}\text { years of } \\
\text { establishment }\end{array}$ & $\begin{array}{l}\text { propensity } \\
\text { score }\end{array}$ \\
\hline \multicolumn{9}{|l|}{ Panel A. Number of Other Provinces the Firm Operates In } \\
\hline $\begin{array}{l}\text { Log total employment (at industry-year level, } \\
\text { excluding own province) }\end{array}$ & $\begin{array}{l}7.338 \\
(5.612)\end{array}$ & $\begin{array}{c}6.759 \\
(4.788)\end{array}$ & $\begin{array}{c}6.722 \\
(4.809)\end{array}$ & $\begin{array}{c}7.354 \\
(4.915)\end{array}$ & $\begin{array}{l}6.886 \\
(4.864)\end{array}$ & $\begin{array}{c}6.672 \\
(4.746)\end{array}$ & $\begin{array}{l}7.569 \\
(4.925)\end{array}$ & $\begin{array}{l}7.803 \\
(5.326)\end{array}$ \\
\hline Number of other provinces in which firm operates & $\begin{array}{l}0.913^{*} \\
(0.500)\end{array}$ & $\begin{array}{c}1.348^{* * *} \\
(0.502)\end{array}$ & $\begin{array}{l}1.328^{* *} \\
(0.502)\end{array}$ & $\begin{array}{l}1.241^{* *} \\
(0.504)\end{array}$ & $\begin{array}{l}1.312^{* *} \\
(0.498)\end{array}$ & $\begin{array}{l}1.361^{* *} \\
(0.655)\end{array}$ & $\begin{array}{c}1.527^{* * *} \\
(0.480)\end{array}$ & $\begin{array}{c}0.809 \\
(0.611)\end{array}$ \\
\hline $\begin{array}{l}\text { Number of other provinces in which firm operates } \mathrm{X} \\
\log \text { (Employ) }\end{array}$ & $\begin{array}{l}-0.055 \\
(0.038)\end{array}$ & $\begin{array}{c}-0.086^{* *} \\
(0.038)\end{array}$ & $\begin{array}{c}-0.083^{* *} \\
(0.037)\end{array}$ & $\begin{array}{c}-0.079^{* *} \\
(0.037)\end{array}$ & $\begin{array}{c}-0.083^{* *} \\
(0.037)\end{array}$ & $\begin{array}{l}-0.087^{*} \\
(0.048)\end{array}$ & $\begin{array}{c}-0.099 * * * \\
(0.036)\end{array}$ & $\begin{array}{l}-0.046 \\
(0.046)\end{array}$ \\
\hline Observations & 10332 & 13061 & 13061 & 13061 & 13061 & 11930 & 12763 & 9350 \\
\hline \multicolumn{9}{|l|}{ Panel B. Dummy for Operating in More than One Province } \\
\hline $\begin{array}{l}\text { Log total employment (at industry-year level, } \\
\text { excluding own province) }\end{array}$ & $\begin{array}{l}7.070 \\
(5.716)\end{array}$ & $\begin{array}{c}6.642 \\
(4.805)\end{array}$ & $\begin{array}{c}6.557 \\
(4.833)\end{array}$ & $\begin{array}{c}7.236 \\
(4.939)\end{array}$ & $\begin{array}{l}6.758 \\
(4.881)\end{array}$ & $\begin{array}{c}6.631 \\
(4.760)\end{array}$ & $\begin{array}{l}7.527 \\
(4.986)\end{array}$ & $\begin{array}{l}7.903 \\
(5.537)\end{array}$ \\
\hline Firm currently operates in more than one province & $\begin{array}{c}3.699 \\
(2.650)\end{array}$ & $\begin{array}{l}5.588^{* *} \\
(2.471)\end{array}$ & $\begin{array}{l}5.627^{* *} \\
(2.500)\end{array}$ & $\begin{array}{l}5.239^{* *} \\
(2.447)\end{array}$ & $\begin{array}{l}5.424^{* *} \\
(2.466)\end{array}$ & $\begin{array}{l}5.345^{* *} \\
(2.578)\end{array}$ & $\begin{array}{l}6.191^{* *} \\
(2.518)\end{array}$ & $\begin{array}{l}3.218 \\
(2.668)\end{array}$ \\
\hline $\begin{array}{l}\text { Firm currently operates in more than one province } \\
\mathrm{X} \log \text { (Employ) }\end{array}$ & $\begin{array}{l}-0.241 \\
(0.198)\end{array}$ & $\begin{array}{c}-0.375^{* *} \\
(0.184)\end{array}$ & $\begin{array}{c}-0.374^{* *} \\
(0.186)\end{array}$ & $\begin{array}{c}-0.350^{*} \\
(0.182)\end{array}$ & $\begin{array}{c}-0.362^{*} \\
(0.183)\end{array}$ & $\begin{array}{c}-0.360^{*} \\
(0.191)\end{array}$ & $\begin{array}{c}-0.418^{* *} \\
(0.187)\end{array}$ & $\begin{array}{l}-0.201 \\
(0.199)\end{array}$ \\
\hline Observations & 10411 & 13158 & 13158 & 13158 & 13158 & 12027 & 12846 & 9418 \\
\hline Control for average firm size $\mathrm{X} \log$ (Employ) & YES & YES & YES & YES & YES & YES & YES & YES \\
\hline Province-industry and year fixed effects & $\checkmark$ & $\checkmark$ & $\checkmark$ & $\checkmark$ & $\checkmark$ & $\checkmark$ & $\checkmark$ & $\checkmark$ \\
\hline
\end{tabular}

Note: Column (1) to (7) controls for the following explanatory variables and their interactions with log total employment of the same industry-year group in all provinces other than own: share of registration documents held, former household firm (dummy), former SOE (dummy), owner being a government official (dummy), government holding positive share (dummy), log of business premise size, firm's age. Column (8) controls for the propensity score. All regressions control for province-industry and year fixed effects. Standard errors are clustered at the province level. ${ }^{* * *}$ implies significance at 0.01 level, ${ }^{* *} 0.5,{ }^{*} 0.1$. 
Table 8: Testing Alternative Models

\begin{tabular}{|c|c|c|c|}
\hline & $\begin{array}{c}\text { (1) } \\
\text { Herfindahl index for } \\
\text { province-industry-year group }\end{array}$ & $\begin{array}{c}\text { (2) } \\
\text { Bribes as \% of revenue } \\
\text { (excluding construction inudustry) }\end{array}$ & $\begin{array}{c}(3) \\
\text { Bribes as } \% \text { of revenue }\end{array}$ \\
\hline $\begin{array}{l}\text { Log total employment } \\
\text { (at industry-year level, excluding own province) }\end{array}$ & $\begin{array}{c}0.067^{* * *} \\
(0.022)\end{array}$ & $\begin{array}{c}-1.728^{* *} \\
(0.844)\end{array}$ & $\begin{array}{c}-1.684^{* *} \\
(0.703)\end{array}$ \\
\hline Log aggregate province-year shock (instrument) & & & $\begin{array}{l}-0.892 \\
(3.396)\end{array}$ \\
\hline Observations & 3561 & 11012 & 13160 \\
\hline
\end{tabular}

Note: The dependent variable for Column (1) is the employment Herfindahl index constructed for each province-industry-year group. The index is normalized to be between 0 and 1 , where a small index indicates a competitive industry. For this regression, we keep 1 obseration per province-industry-year group. Column (2) shows the result for the main reduced form regression but excluding firms in the construction industry. For column (3), we construct an instrument for aggregate province-year level shock and include it in the main baseline specification. The instrument is log of the weighted sum over all industries of province (excluding own)-industry-year employment, normalized by the average over all years of total employment in the industry in other provinces. The weight is the average over all years of industry's share of employment in the province. All regressions control for province-industry and year fixed effects. Standard errors are clustered at the province level. $* * *$ implies significance at 0.01 level, ${ }^{* *} 0.5,{ }^{*} 0.1$. 


\section{FOR ONLINE PUBLICATION}

\section{Appendix Tables}

Appendix Table 1: Industry Codes and Descriptions

\begin{tabular}{cl}
\hline \hline ISIC Rev 4 Code & Description \\
A & Agriculture, forestry and fishing \\
B & Mining and quarrying \\
C & Manufacturing \\
D & Electricity, gas, steam and air conditioning supply \\
E & Water supply; sewerage, waste management and remediation activities \\
F & Construction \\
G & Wholesale and retail trade; repair of motor vehicles and motorcycles \\
H & Transportation and storage \\
I & Accommodation and food service activities \\
J & Information and communication \\
K & Financial and insurance activities \\
L & Real estate activities \\
M & Professional, scientific and technical activities \\
N & Administrative and support service activities \\
P & Education \\
Q & Human health and social work activities \\
R & Arts, entertainment and recreation \\
S & Other service activities \\
\hline
\end{tabular}

The alphabetical industry codes and descriptions are based on International Standard Industrial Classification (ISIC) of All Economic Activities, Rev.4. The list includes the 18 industries that appear in our analysis sample. 
Appendix Table 2: Cross-Validation of PCI and GSO Data

\begin{tabular}{|c|c|c|}
\hline \multirow[b]{2}{*}{ Log mean Employment in GSO } & $\begin{array}{l}\text { (1) } \\
\text { Log mean Employment } \\
\text { in PCI data }\end{array}$ & $\begin{array}{c}\text { (2) } \\
\text { Log median Employment } \\
\text { in PCI data }\end{array}$ \\
\hline & $\begin{array}{c}0.531^{* * *} \\
(0.041)\end{array}$ & \\
\hline Log median Employment in GSO & & $\begin{array}{c}0.478 * * * \\
(0.047)\end{array}$ \\
\hline Observations & 4607 & 4607 \\
\hline Province-industry and year fixed effects & $\checkmark$ & $\checkmark$ \\
\hline \multicolumn{3}{|c|}{$\begin{array}{l}\text { Note: Each observation is a province-industry-year. The dependent variable is log mean or log median firm-level } \\
\text { employment for each province-industry-year group in the PCI data. The independent variable is the corresponding } \\
\text { variable computed using the GSO data. For both datasets, we keep only private firms. Since the firm employment } \\
\text { variable in PCI is categorical, we compute the empirical mean and median for each category from the GSO data and } \\
\text { apply these to the PCI data. All specifications control for province by industry and year fixed effect. Industries refer } \\
\text { to ISIC 2-digit industry code. Robust standard errors are clustered at the province level and reported. *** implies } \\
\text { significance at } 0.01 \text { level, }{ }^{* *} 0.5, * 0.1 \text {. }\end{array}$} \\
\hline
\end{tabular}


Appendix Table 3: Propensity Score Regressions for LURC and Operation Locations

\begin{tabular}{lccc}
\hline \hline & $(1)$ & $(2)$ & $(3)$ \\
& Firm has & Number of other provinces & Firm currently operates \\
Share of registration documents held & LURC & in which firm operates & in more than one province \\
\cline { 2 - 4 } & $0.784^{* * *}$ & $0.663^{* * *}$ & $0.493^{* * *}$ \\
Former HH firm (dummy) & $(0.092)$ & $(0.156)$ & $(0.110)$ \\
& $0.453^{* * *}$ & 0.033 & 0.054 \\
Former SOE (dummy) & $(0.052)$ & $(0.090)$ & $(0.060)$ \\
& $0.184^{* *}$ & $0.453^{* * *}$ & $0.239^{* *}$ \\
Owner is government official (dummy) & $(0.090)$ & $(0.136)$ & $(0.100)$ \\
& $0.389^{* *}$ & 0.251 & 0.284 \\
Government holds positive share (dummy) & $(0.151)$ & $(0.273)$ & $(0.184)$ \\
& $\left(0.160^{* * *}\right.$ & 0.119 & 0.095 \\
Log of business premise size (hectare) & $0.274^{* * *}$ & $(0.181)$ & $(0.131)$ \\
& $(0.017)$ & 0.007 & $0.029^{*}$ \\
Years since establishment & $0.059^{* * *}$ & $(0.021)$ & $(0.015)$ \\
Observations & $(0.005)$ & $0.015^{* * *}$ & $0.011^{* * *}$ \\
\hline
\end{tabular}

Note: Column (1) shows the logit regression coefficients of LURC (dummy) on various predictors of obtaining the certificate, including share of registration documents held, former household firm (dummy), former SOE (dummy), owner being a government official (dummy), government holding positive share (dummy), log of business premise size, and firm's age. Column (2) and (3) show the (ordered) logit regression results for firm's operation location variables on the same set of explanatory variables. *** implies significance at 0.01 level, ** $0.5, * 0.1$. 
Appendix Table 4: Heterogeneous Effects Based on Firms' Property Rights (Contemporaneous Measure of LURC)

Dependent variable: Firm's bribe payment as percentage of revenue

\begin{tabular}{|c|c|c|c|c|}
\hline \multirow{3}{*}{ Log total employment (at industry-year level, excluding own province) } & (1) & $(2)$ & $(3)$ & $(4)$ \\
\hline & $-1.534^{* *}$ & 7.930 & $-1.570^{* *}$ & 7.803 \\
\hline & $(0.762)$ & $(5.514)$ & $(0.760)$ & $(5.571)$ \\
\hline \multirow[t]{2}{*}{ Firm owns land and has LURC } & $3.939 * *$ & $3.858^{* *}$ & 2.448 & 2.393 \\
\hline & $(1.792)$ & $(1.783)$ & $(2.193)$ & $(2.214)$ \\
\hline \multirow[t]{2}{*}{ Firm owns land and has LURC X $\log$ (Employ) } & $-0.290^{* *}$ & $-0.284^{* *}$ & -0.213 & -0.209 \\
\hline & $(0.132)$ & $(0.131)$ & $(0.162)$ & $(0.164)$ \\
\hline \multirow{2}{*}{ Firm owns its land } & & & 2.235 & 2.198 \\
\hline & & & $(2.169)$ & $(2.167)$ \\
\hline \multirow[t]{2}{*}{ Firm owns its land X $\log$ (Employ) } & & & -0.114 & -0.111 \\
\hline & & & $(0.164)$ & $(0.163)$ \\
\hline Observations & 11486 & 11486 & 11486 & 11486 \\
\hline Control for average firm size $\mathrm{X} \log$ (Employ) & NO & YES & $\mathrm{NO}$ & YES \\
\hline Province-industry and year fixed effects & $\checkmark$ & $\checkmark$ & $\checkmark$ & $\checkmark$ \\
\hline
\end{tabular}

Note: This table presents results for the same specifications as in Table 4 but using contemporaneous Measure of LURC. 
Appendix Table 5: Heterogeneous Effects Based on Firms' Property Rights (Ordered Probit)

Dependent variable: Firm's bribe payment as percentage of revenue

\begin{tabular}{lccc}
\hline \hline & $(1)$ & $(2)$ & $(3)$ \\
& $\begin{array}{c}\text { Firms that rent } \\
\text { their land }\end{array}$ & $\begin{array}{c}\text { Firms that own } \\
\text { land without LURC }\end{array}$ & $\begin{array}{c}\text { Firms that own } \\
\text { land with LURC }\end{array}$ \\
\cline { 2 - 4 } Log total employment & -0.018 & 0.638 & -0.396 \\
(at industry-year level, excluding own province) & $(0.247)$ & $(0.461)$ & $(0.257)$ \\
Observations & 3610 & 1760 & 5183
\end{tabular}

Province-industry and year fixed effects

$\checkmark \quad \checkmark \quad \checkmark$

Note: This table reports the reduced form results using the ordered probit model for firms in three categories: (1) firms that rent their land; (2) firms that own land without an LURC; (3) firms that own land with an LURC. All regressions control for province-industry and year fixed effects. Standard errors are clustered at the province level. ${ }^{* * *}$ implies significance at 0.01 level, ${ }^{* *} 0.5, * 0.1$. 


\section{Appendix: Mathematical Details of the Model}

This Appendix proves Propositions 1 and 2. One way to prove the results is using standard first order condition and taking derivative by invoking implicit function theorem. Here we explore an alternative method. First notice that by replacing $K, L, A, \theta$ by $r K, w L, \frac{A}{r^{\alpha} w^{\beta}}, \theta\left(r^{\alpha} w^{\beta}\right)^{\eta}$, we can assume $w=r=1$ without changing the problem. This linear change of variable also preserves the signs of the derivatives in question. We thus have

$$
\pi_{1}^{*}=\max _{K, L \geq 0}\left(1-b_{1}\right) A K^{\alpha} L^{\beta}-K-L
$$

which gives

$$
\begin{aligned}
K_{1}^{*} & =\alpha\left(\left(1-b_{1}\right) A \alpha^{\alpha} \beta^{\beta}\right)^{\frac{1}{1-\alpha-\beta}} \\
L_{1}^{*} & =\beta\left(\left(1-b_{1}\right) A \alpha^{\alpha} \beta^{\beta}\right)^{\frac{1}{1-\alpha-\beta}} \\
\pi_{1}^{*} & =(1-\alpha-\beta)\left(\left(1-b_{1}\right) A \alpha^{\alpha} \beta^{\beta}\right)^{\frac{1}{1-\alpha-\beta}}
\end{aligned}
$$

Substituting these into the government's problem, we are able to calculate the total bribe received by government in province 1 :

$$
B_{1}=t\left(1-\lambda\left(R_{2}-R_{1}\right)\right)\left(R_{1}^{\alpha+\beta}-R_{1}\right)
$$

where

$$
\begin{aligned}
R_{1} & =\left(1-b_{1}\right)^{\frac{1}{1-\alpha-\beta}} \\
R_{2} & =\left(1-b_{2}\right)^{\frac{1}{1-\alpha-\beta}} \\
\lambda & =\frac{A^{\frac{1}{1-\alpha-\beta}}}{\theta A^{\eta}}(1-\alpha-\beta)\left(\alpha^{\alpha} \beta^{\beta}\right)^{\frac{1}{1-\alpha-\beta}} \\
t & =\left(A \alpha^{\alpha} \beta^{\beta}\right)^{\frac{1}{1-\alpha-\beta}}
\end{aligned}
$$

Instead of choosing $b_{1}, b_{2} \in(0,1)$, the two provinces could choose $R_{1}, R_{2} \in(0,1)$ as well. The FOC for (1) then yields

$$
\lambda\left(R_{1}^{\alpha+\beta}-R_{1}\right)=\left(1-\lambda\left(R_{2}-R_{1}\right)\right) *\left(1-(\alpha+\beta) R_{1}^{\alpha+\beta-1}\right)
$$

The symmetric equilibrium $R_{1}=R_{2}=R^{*}$ must then satisfy

$$
\lambda\left(R_{1}^{\alpha+\beta}-R_{1}\right)=1-(\alpha+\beta) R_{1}^{\alpha+\beta-1}
$$

This gives the equilibrium bribe rate $b^{*}$ via (2).

Proposition 1. $\frac{d b^{*}}{d \log A}<0$ if $0 \leq \eta<\frac{1}{1-\alpha-\beta} ;=0$ if $\eta=\frac{1}{1-\alpha-\beta} ;>0$ if $\eta>\frac{1}{1-\alpha-\beta}$.

Proof. : Re-arrange (7) and notice that the ratio

$$
\phi:=\frac{1-(\alpha+\beta) R_{1}^{\alpha+\beta-1}}{\left(R_{1}^{\alpha+\beta}-R_{1}\right)}
$$

is strictly increasing in $R$, because $R_{1}^{\alpha+\beta}-R_{1}$ is concave and hence log-concave in $R$. Therefore, (7) has a unique solution for fixed parameters (so fixed $\lambda$ ), and this solution is strictly increasing 
in $\lambda$. In other words,

$$
\frac{d R^{*}}{d \lambda}>0
$$

From (2), $b^{*}=1-\left(R^{*}\right)^{1-\alpha-\beta}$, and so $\frac{d b^{*}}{d R^{*}}<0$. Also from (4), $\frac{d \lambda}{d A}$ is positive when $\eta<\frac{1}{1-\alpha-\beta}$ and negative otherwise. Multiplying the three inequalities, we obtain

$$
\begin{aligned}
& \frac{d b^{*}}{d A}>0, \text { when } \eta>\frac{1}{1-\alpha-\beta} \\
& \frac{d b^{*}}{d A}<0, \text { when } \eta<\frac{1}{1-\alpha-\beta}
\end{aligned}
$$

Proposition 2. The elasticity $-\frac{d b^{*}}{d A} \frac{A}{b^{*}}$ is monotonically decreasing in $\theta$ when $0 \leq \eta<\frac{1}{1-\alpha-\beta}$.

Proof. : From (2),

$$
\epsilon_{R^{*}}=\frac{1}{1-\alpha-\beta} \frac{b^{*}}{1-b^{*}} \epsilon_{b^{*}}
$$

where $\epsilon_{R}=\frac{d R}{d A} \frac{A}{R}$ and $\epsilon_{b}=-\frac{d b}{d A} \frac{A}{b}$. Taking the derivative of (7) with respect to $A$, we get (omitting stars)

$$
\epsilon_{\lambda}:=\frac{1}{1-\alpha-\beta}-\eta=\left(\frac{(\alpha+\beta)(1-\alpha-\beta) R^{\alpha+\beta-1}}{1-(\alpha+\beta) R^{\alpha+\beta-1}}+\frac{R-(\alpha+\beta) R^{\alpha+\beta}}{R^{\alpha+\beta}-R}\right) \epsilon_{R}
$$

Substitute (9) and (2) into (10), we have

$$
\frac{\epsilon_{\lambda}}{\epsilon_{b}}=\left((\alpha+\beta) R^{\alpha+\beta-2}+\frac{R^{\alpha+\beta-1}-1}{(1-\alpha-\beta) R}\right) \phi^{-1}
$$

It is easy to see that $b^{*}\left(R^{*}\right)$ increases (decreases) with $\theta$, and thus the right hand side increases with $\theta$. Therefore,

$$
\frac{d \epsilon_{b^{*}}}{d \theta}<0, \text { when } \epsilon_{\lambda}>0 \Leftrightarrow \eta<\frac{1}{1-\alpha-\beta}
$$

